\title{
Systematic Tuning of Fluoro-galectin-3 Interactions Provides Thiodigalactoside Derivatives with Single-Digit nM Affinity and High Selectivity
}

Kristoffer Peterson, ${ }^{\dagger}$ Rohit Kumar, ${ }^{\dagger}$ Olof Stenström, ${ }^{\S}$ Priya Verma, ${ }^{\dagger}$ Prashant R. Verma, ${ }^{\dagger}$ Maria Håkansson, ${ }^{\|}$Barbro Kahl-Knutsson, ${ }^{\perp}$ Fredrik Zetterberg, ${ }^{\#}$ Hakon Leffler, ${ }^{\perp}$ Mikael Akke, ${ }^{\S}$ Derek T. Logan, ${ }^{\neq, \| \odot}$ and Ulf J. Nilsson*, ${ }^{\dagger}$

${ }^{\dagger}$ Centre for Analysis and Synthesis, Department of Chemistry, Lund University, Box 124, SE-221 00 Lund, Sweden

${ }^{\ddagger}$ Biochemistry and Structural Biology, Center for Molecular Protein Science, Department of Chemistry, Lund University, Box 124, SE-221 00 Lund, Sweden

${ }^{\S}$ Biophysical Chemistry, Center for Molecular Protein Science, Department of Chemistry, Lund University, Box 124, SE-221 00 Lund, Sweden

"SARomics Biostructures AB, Medicon Village, SE-223 63 Lund, Sweden

${ }^{\perp}$ Department of Laboratory Medicine, Section MIG, Lund University BMC-C1228b, Klinikgatan 28, 22184 Lund, Sweden

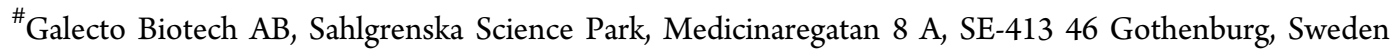

Supporting Information

ABSTRACT: Symmetrical and asymmetrical fluorinated phenyltriazolyl-thiodigalactoside derivatives have been synthesized and evaluated as inhibitors of galectin-1 and galectin-3. Systematic tuning of the phenyltriazolyl-thiodigalactosides' fluoro-interactions with galectin-3 led to the discovery of inhibitors with exceptional affinities $\left(K_{\mathrm{d}}\right.$ down to $\left.1-2 \mathrm{nM}\right)$ in symmetrically substituted thiodigalactosides as well as unsurpassed combination of high affinity $\left(K_{\mathrm{d}} 7.5 \mathrm{nM}\right)$ and selectivity (46-fold) over galectin-1 for asymmetrical thiodigalactosides by carrying one trifluorphenyltriazole and one coumaryl moiety. Studies of the inhibitor-galectin complexes with isothermal titration calorimetry and X-ray crystallography revealed the importance of fluoro-amide interaction for affinity and for selectivity. Finally, the high affinity of the discovered inhibitors required two competitive titration assay tools to be developed: a new high affinity fluorescent probe for competitive fluorescent polarization and a competitive ligand optimal for analyzing high affinity galectin-3 inhibitors with competitive isothermal titration calorimetry.

\section{INTRODUCTION}

Galectins are a family of glycan-binding proteins known for their ability to cross-link glycoconjugates to form lattices. They are defined by their affinity for $\beta$-D-galactopyranoside moieties and their possession of a conserved carbohydrate-recognition domain $(\mathrm{CRD}) .{ }^{1}$ Prototype galectins $(1,2,5,7,10,11,13,14$, and 15) exists as monomers with one $\mathrm{CRD}$, which dimerize at higher concentrations. Galectins $(4,6,8,9$, and 12) are of the tandem-repeat type with two different CRDs joined by a linker polypeptide, and galectin-3 is a chimera-type protein with a single CRD and a nonlectin $\mathrm{N}$-terminal domain that promotes oligomerization. ${ }^{2}$ Galectin lattices have been proposed to influence the behavior and activities of cross-linked glycoconjugates by regulating their cellular trafficking, localization, residence times, and molecular interactions. Interactions of galectin-3, the most extensively studied family member, with glycoconjugates control cell properties and functions and cell adhesion and have modulatory effects on the immune system, ${ }^{3}$ tumor growth and metastasis, ${ }^{4}$ which suggests that galectin-3
CRD inhibitors can be used as therapeutic agents. This has been validated by several ex vivo ${ }^{5,6}$ and in vivo ${ }^{7,8}$ studies.

Selective small-molecule galectin- 3 inhibitors are not only valuable as research tools but also as drug candidates. Small molecule derivatives often involve lactose-based derivatives, ${ }^{7,9-12} 1$ - and 3-substitutions of galactose $e^{13-17}$ or 3,3'disubstitution of thiodigalactoside. Other strategies involve multivalent inhibitors. ${ }^{18-22}$ The highest affinity small-molecule galectin-3 inhibitors achieve low $\mathrm{nM}$ affinity by 3-benzamido-, ${ }^{23,24} 3$-O-coumarylmethyl, ${ }^{25,26}$ 4-amido-1,2,3-triazolyl, ${ }^{27}$ or 4-aryl-1,2,3-triazolyl ${ }^{28}$ substitutions at the 3- and 3'-positions of thiodigalactoside. Recently, X-ray structural analysis ${ }^{28}$ of the two galectin-3 CRD (galectin-3C) complexes with bis-[4-(3fluorophenyl)-1,2,3-triazol-1-yl] or bis-[4-(4-fluorophenyl)1,2,3-triazol-1-yl] thiodigalactosides $\mathbf{1}$ and $\mathbf{2}$ (Figure 1) revealed two types of important interactions, namely guanidine-arene

Received: November 4, 2017

Published: December 28, 2017 


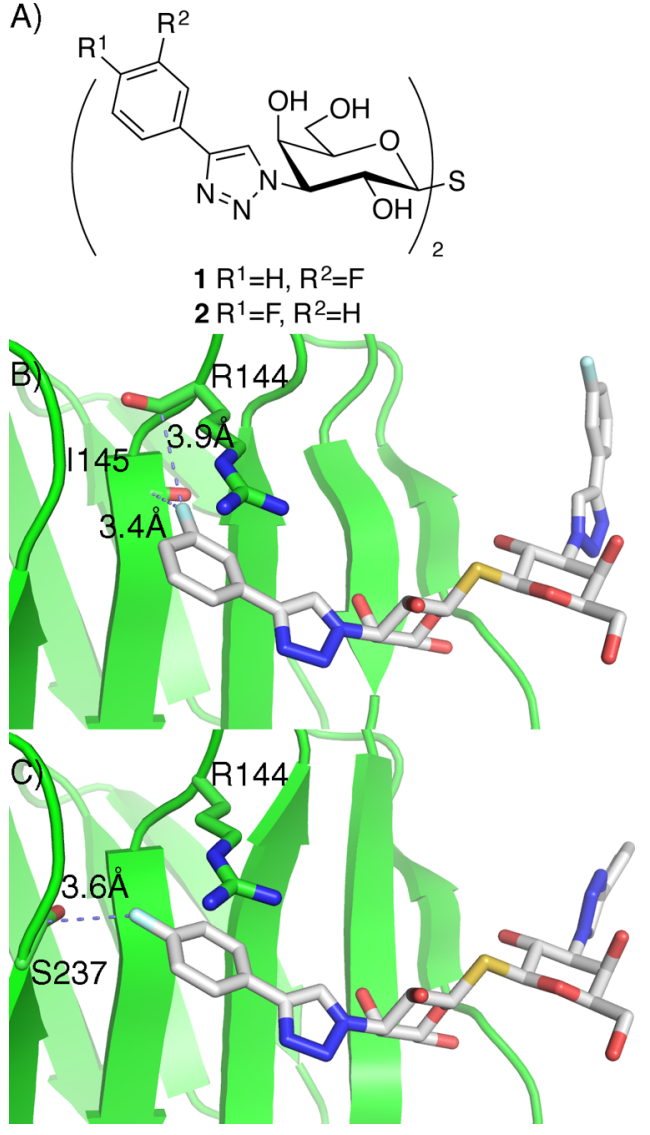

Figure 1. (A) 3- and 4-Fluorophenyl thiodigalactoside derivatives 1 and 2 with high affinity for galectin-3. ${ }^{28}(\mathrm{~B}, \mathrm{C})$ Galectin-3C in complexes with compounds 1 and 2 . The R144 side chain atop the monofluorophenyl is highlighted for clarity. Orthogonal multipolar fluorine interactions between compound $\mathbf{1}$ and the carbonyl groups of R144 and I145 and between compound 2 and the carbonyl group of S237 are depicted with dashed lines.

interactions, involving R144 and R186 and the aryls of 1 or 2, and orthogonal multipolar fluorine-amide interactions ${ }^{29}$ involving the backbone amides of R144 and I145 and the fluorine atom of $\mathbf{1}$ or the backbone amide of S237 with the fluorine atom of $\mathbf{2}$. This observation suggests that fluorineamide interactions are attractive design motifs toward discovery of high-affinity ligands of lectins that have inherently low affinity for natural saccharide fragments.

Herein, we report thiogalactoside and thiodigalactoside derivatives carrying one or two mono- to trifluorinated 3-(4aryl-1,2,3-triazol-1-yl) moieties at thiodigalactoside C3 and C3' toward the discovery of galectin-3 ligands with improved selectivity and affinity. Additionally, an in-depth analysis of competitive fluorescence polarization and competitive isothermal titration calorimetry assays used for evaluating galectin3 ligands with very high affinity is reported.

\section{RESULTS AND DISCUSSION}

Synthesis and Galectin-3 Affinities of 3-(4-Aryl-1,2,3triazol-1-yl)-thiogalactosides. Deprotection and acetylation of azide $3^{30}$ to azide 4 allowed the synthesis of a library of 1,4disubstituted triazoles 5-16 at the C3-galactose position by a 1,3-dipolar cycloaddition and subsequent deacetylation (Scheme 1).
Scheme 1. Synthesis of Triazoles 5-16
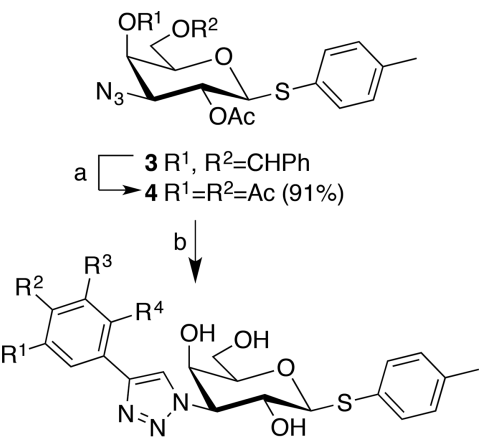

$5 \mathrm{R}^{1}=\mathrm{R}^{2}=\mathrm{R}^{3}=\mathrm{R}^{4}=\mathrm{H}(37 \%)$

$6 \mathrm{R}^{1}=\mathrm{R}^{2}=\mathrm{R}^{3}=\mathrm{H}, \mathrm{R}^{4}=\mathrm{F}(81 \%)$

$7 R^{1}=R^{2}=R^{4}=H, R^{3}=F(91 \%)$

$8 R^{1}=R^{3}=R^{4}=H, R^{2}=F(86 \%)$

$9 \mathrm{R}^{1}=\mathrm{R}^{4}=\mathrm{H}, \mathrm{R}^{2}=\mathrm{R}^{3}=\mathrm{F}(87 \%)$

$10 R^{2}=R^{4}=H, R^{1}=R^{3}=F(92 \%)$

$11 \mathrm{R}^{4}=\mathrm{H}, \mathrm{R}^{1}=\mathrm{R}^{2}=\mathrm{R}^{3}=\mathrm{F}(98 \%)$

$12 \mathrm{R}^{1}=\mathrm{R}^{4}=\mathrm{H}, \mathrm{R}^{2}=\mathrm{F}, \mathrm{R}^{3}=\mathrm{Me}(98 \%)$

$13 \mathrm{R}^{1}=\mathrm{R}^{2}=\mathrm{R}^{4}=\mathrm{H}, \mathrm{R}^{3}=\mathrm{Cl}(97 \%)$

$14 \mathrm{R}^{1}=\mathrm{R}^{3}=\mathrm{R}^{4}=\mathrm{H}, \mathrm{R}^{2}=\mathrm{Cl}(53 \%)$

$15 \mathrm{R}^{1}=\mathrm{R}^{4}=\mathrm{H}, \mathrm{R}^{2}=\mathrm{R}^{3}=\mathrm{Cl}(72 \%)$

$16 \mathrm{R}^{1}=\mathrm{R}^{3}=\mathrm{R}^{4}=\mathrm{H}, \mathrm{R}^{2}=\mathrm{Br}(31 \%)$

${ }^{a}$ Reagents and conditions: (a) (i) $\mathrm{AcOH}(90 \%), 90^{\circ} \mathrm{C}$, 4 h, (ii) $\mathrm{Ac}_{2} \mathrm{O}$, pyridine, rt; (b) (i) alkyne, CuI, DIPEA, $\mathrm{MeCN}, 50{ }^{\circ} \mathrm{C}$, (ii) $\mathrm{NaOMe}$, $\mathrm{MeOH}$, rt.

As thiodigalactosides $\mathbf{1}$ and $\mathbf{2}$ showed high affinities for both galectin-1 and galectin-3, we evaluated the inhibition potencies of triazoles 5-16, together with reference compound $p$ methylphenyl 1 -thio- $\beta$-D-galactopyranoside 17 (Table 1),

Table 1. $K_{d}(\mu \mathrm{M})$ Values for Monogalactoside Triazoles 516 and Reference 17 Determined by Competitive Fluorescence Polarization

\begin{tabular}{llcc} 
& galectin-1 & galectin-3 & galectin-1/galectin-3 \\
$\mathbf{5}$ & $220 \pm 6$ & $88 \pm 3$ & 2.5 \\
$\mathbf{6}$ & $190 \pm 13$ & $92 \pm 5$ & 2.1 \\
7 & $180 \pm 7$ & $22 \pm 0.7$ & 8.2 \\
$\mathbf{8}$ & $140 \pm 6$ & $31 \pm 1.3$ & 4.5 \\
$\mathbf{9}$ & $530 \pm 40$ & $8.8 \pm 0.3$ & 60 \\
$\mathbf{1 0}$ & $290 \pm 9$ & $15 \pm 0.3$ & 19 \\
$\mathbf{1 1}$ & $180 \pm 12$ & $5.2 \pm 0.3$ & 35 \\
$\mathbf{1 2}$ & $170 \pm 2$ & $23 \pm 1.0$ & 7.4 \\
$\mathbf{1 3}$ & $100 \pm 2$ & $44 \pm 1.1$ & 2.3 \\
$\mathbf{1 4}$ & $680 \pm 80$ & $19 \pm 1.0$ & 36 \\
$\mathbf{1 5}$ & $120 \pm 8$ & $14 \pm 1.3$ & 8.6 \\
16 & $300 \pm 20$ & $44 \pm 3.9$ & 6.8 \\
$\mathbf{1 7}$ & $1100 \pm 110$ & $230 \pm 30$ & 4.7 \\
\hline
\end{tabular}

toward galectin-1 and galectin-3 using a previously described competitive fluorescence polarization assay. ${ }^{31,32}$ All monogalactoside triazoles 5-16 bound galectin- 1 and galectin- 3 better than the unsubstituted thiogalactoside 17, and all phenyltriazoles except 6 showed better galectin-3 binding than the unsubstituted phenyltriazole 5 . The galectin- 3 affinities revealed that meta- and para-fluorination (7-8), meta- and parachlorination (13-14), or para-bromination (16) increase binding. Additional fluorination (9-11) or chlorination (15) further increased binding, with the trifluorophenyltriazole 11 showing remarkably high affinity, for a monosaccharide ligand, toward galectin-3. These results provided a basis for selecting 
phenyltriazolyl structures to implement and investigate on a thiodigalactoside scaffold and triazolylthiodigalactoside analogues (19-21) of the three best monogalactosides (9-11) were selected for synthesis.

Synthesis and Galectin-3 Affinities of Symmetrical Bis-3-(4-aryl-1,2,3-triazol-1-yl)-thiodigalactosides. Three symmetrical tetra- or hexafluorinated bis-3-(4-aryl-1,2,3-triazol1-yl)-thiodigalactosides 19-21 were synthesized in order to compare with the known monofluorinated phenyl groups of 12. Compounds 19-21 were obtained in good yields from the known diazide $18{ }^{33}$ following similar conditions to those used for the synthesis of monogalactoside triazoles 5-16 (Scheme 2).

Scheme 2. Synthesis of Triazoles $19-21^{a}$

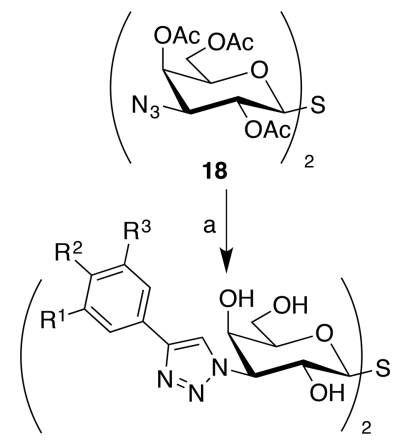

$19 \mathrm{R}^{1}=\mathrm{H}, \mathrm{R}^{2}=\mathrm{R}^{3}=\mathrm{F}(91 \%)$

$20 \mathrm{R}^{2}=\mathrm{H}, \mathrm{R}^{1}=\mathrm{R}^{3}=\mathrm{F}(88 \%)$

$21 R^{1}=R^{2}=R^{3}=F(77 \%)$

${ }^{a}$ Reagents and conditions: (a) (i) alkyne, CuI, DIPEA, DMF, $50{ }^{\circ} \mathrm{C}$, (ii) $\mathrm{NaOMe}, \mathrm{MeOH}, \mathrm{CH}_{2} \mathrm{Cl}_{2}$, rt.

Evaluation of potentially very high affinity inhibitors, such as 19-21, in competitive fluorescence polarization assays ${ }^{31}$ requires that the competitive fluorescent probe molecule also possesses high affinity for galectin-3 in order to allow lower experimental concentrations of the probe molecule and the protein in the range of, or ideally lower than, the anticipated dissociation constants for the inhibitors. Hence, having discovered that the derivatives 9-11 were indeed potent monogalactoside inhibitors compared to the corresponding unsubstituted galactoside 17 , we designed and synthesized fluorescent probe molecules 25-26 based on thiodigalactoside equipped with the affinity-enhancing mono- and trifluorophenyltriazole moieties discovered on the monogalactosides 7 and 11, respectively (Scheme 3 ).

Indeed, high affinity toward galectin-3 was observed for both fluorescent probes 25-26 while affinities were significantly lower for galectin-1 (Table 2, Figures S1-S2 in the Supporting Information). Furthermore, a 3-fold higher affinity and 4-fold better galectin-3-selectivity of the trifluoride $\mathbf{2 6}$ over the monofluoride 25 confirms the importance of the multiple fluoro substituents for galectin-3 affinity and selectivity, thus reflecting the differences seen between the monosaccharides 7 and 11. The high affinity of 26 for galectin-3 allowed for competitive fluorescence polarization experiments at lower concentrations of both the probe $26(4.0 \mathrm{nM})$ and galectin-3 $(10.0 \mathrm{nM})$, resulting in improved assay sensitivity and accuracy. A blocking protein (100 nM BSA) was required to prevent perturbing absorption losses at such low concentrations. These assay conditions were used for evaluation of the symmetrical thiodigalactosides $1-2^{28}$ and $19-21$ as inhibitors of galectin-3
Scheme 3. Synthesis of Fluorescent Probes 25-26 ${ }^{a}$
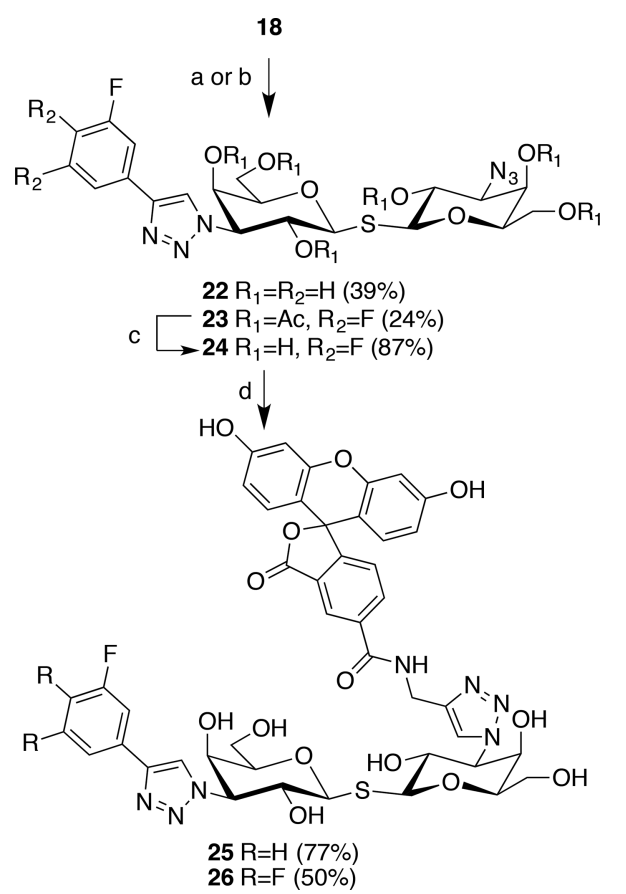

${ }^{a}$ Reagents and conditions: (a) 3,4,5-trifluorophenylacetylene, CuI, DIPEA, DMF, $50{ }^{\circ} \mathrm{C}, 1 \mathrm{~h}$; (b) (i) 3-fluorophenylacetylene, CuI, DIPEA, DMF, rt, 40 min, (ii) $\mathrm{NaOMe}, \mathrm{MeOH}, \mathrm{rt}$; (c) $\mathrm{NaOMe}$, $\mathrm{MeOH}, \mathrm{CH}_{2} \mathrm{Cl}_{2}$, rt; (d) 5-FAM alkyne, CuI, DIPEA, DMF, $50{ }^{\circ} \mathrm{C}, 24$ h.

Table 2. $K_{\mathrm{d}}(\mathrm{nM})$ Values for Symmetrical Thiodigalacosides 1-2, 19-21, and references 27-29 Determined by Competitive Fluorescence Polarization and for Probes 2526 with Direct Fluorescence Polarization Titration

\begin{tabular}{lccc} 
& galectin-1 & galectin-3 & galectin-1/galectin-3 \\
$\mathbf{1}$ & $12^{28}$ & $2.3 \pm 0.2$ & 5.2 \\
$\mathbf{2}$ & $27^{28}$ & $4.0 \pm 0.6$ & 6.8 \\
$\mathbf{1 9}$ & $<10$ & $1.1 \pm 0.2$ & $<9$ \\
$\mathbf{2 0}$ & $63 \pm 15$ & $1.6 \pm 0.3$ & 39 \\
$\mathbf{2 1}$ & $69 \pm 5$ & $2.3 \pm 0.4$ & 30 \\
$\mathbf{2 5}$ & $390 \pm 12$ & $28 \pm 2$ & 14 \\
$\mathbf{2 6}$ & $500 \pm 15$ & $8.7 \pm 0.4$ & 57 \\
$\mathbf{2 7}$ & $24000^{24}$ & $49000^{24}$ & 0.5 \\
$\mathbf{2 8}$ & $3900^{26}$ & $57 \pm 4$ & 68 \\
$\mathbf{2 9}$ & $230 \pm 30$ & $99 \pm 4$ & 2.3 \\
\hline
\end{tabular}

(Table 2). For comparison, we also included as reference compounds unsubstituted thiodigalactoside $\mathbf{2 7}$ and the more galectin-3 selective bis-coumaryl thiodigalactoside $28^{26}$ and bisbutylaminocarbonyltriazolyl thiodigalactoside $29^{27}$ (Figure 2). It is important to note that the improved 26-based assay yielded galectin-3 affinities in the same range as previously determined for compounds $\mathbf{1 - 2 ,},^{28} \mathbf{2 8},{ }^{26}$ and $29 .{ }^{27}$ All compounds except 19 bound galectin-1 with double-digit $\mathrm{nM}$ affinity or worse, thus it was decided that a previously reported fluorescent probe ${ }^{28}$ was sufficient to evaluate galectin-1 affinity of 1-2, 19-21, and 29.

The symmetrical thiodigalactosides 19-21 had much higher affinity for galectin-1 and galectin-3 than did the unsubstituted thiodigalactoside 27. Although we measured galectin-3 affinity on at least two separate occasions and obtained data with 


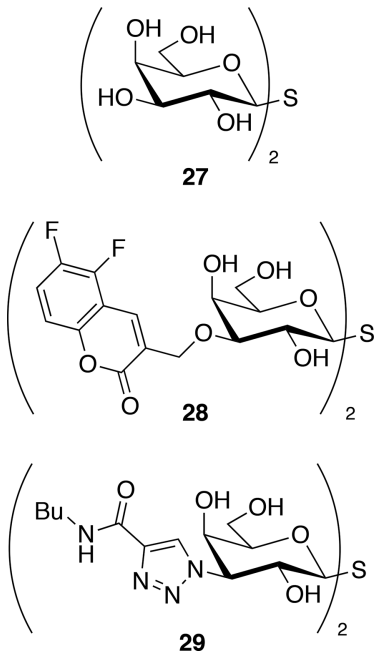

Figure 2. Reference compounds 27-29.

statistical accuracy, we find it difficult, even with our improved assay with the probe molecule 26 , to differentiate between compounds with $<10 \mathrm{nM}$ galectin-3 affinity, such as thiodigalactosides 1-2 and 19-21. To differentiate between these thiodigalactosides confirmation from a second binding assay, such as ITC, was required and is described below. Galectin-1 affinity trends for 19-21 are somewhat surprising when compared to the monosaccharide triazoles 9-11. The 3,4-difluorophenyltriazole 19 had a 7-10-fold higher affinity than 20 and 21, indicating a more favorable interaction of the difluorophenyl in $\mathbf{1 9}$ with the galectin-1 site near R73, which is the conserved arginine residue of galectin-1 corresponding to R186 in galectin-3.

Di- and trifluorinated phenyltriazoles 20-21 have high affinity and show a 6-fold increased selectivity for galectin-3 compared to monofluorinated phenyltriazoles 1-2, a similar increase in selectivity was also observed between fluorescent probe molecules 25-26 where the two extra fluoro substituents in 26 increase selectivity 4 -fold compared to 25 . The increased galectin-3 selectivity of fluorescent probe $\mathbf{2 6}$ also makes it more suitable as a tool in elucidating the biological functions of galectin-3. Still, although thiodigalactosides 20-21 and 26 have superior affinity for galectin-3, they are not as selective as the lower affinity dicoumarylmethyl thiodigalactoside $\mathbf{2 8}$. To study galectin-3 selectivity further, we decided to combine the monofluoro- and the trifluorophenyl moieties of $\mathbf{1}$ and $\mathbf{2 1}$, respectively, with thiodigalactosides $\mathbf{2 8}$ and $\mathbf{2 9}$, as well as combining the coumaryl group of $\mathbf{2 8}$ with a triazolyl group of 29, into asymmetrical thiodigalactosides.

Synthesis and Galectin-3 Affinities of Asymmetrical Mono-3-(1,2,3-triazol-1-yl)-thiodigalactosides. The key step to making the asymmetrical thiodigalactosides 35-37 (Scheme 4) was the $S$-glycosylation of the thiogalactoside donor 33 and the galactoside acceptor $34,{ }^{34}$ facilitated by tetrabutylammonium fluoride, to give thiodigalactoside 35 . Thiogalactoside donor 33 was prepared, starting from the known propargyl derivative $30,{ }^{35}$ following a published $^{36}$ procedure for making 3-O-coumarylmethylgalactosides. Asymmetrical thiodigalactosides 36-38 were then obtained from thiodigalactoside 35 through a 1,3-dipolar cycloaddition and subsequent deacetylation by either sodium methoxide or butylamine in methanol. Asymmetrical bis-triazolyl thiodigalactoside 39 (Scheme 5) was obtained by treating thiodigalacto-
Scheme 4. Synthesis of Asymmetrical Thiodigalactosides $36-38^{a}$
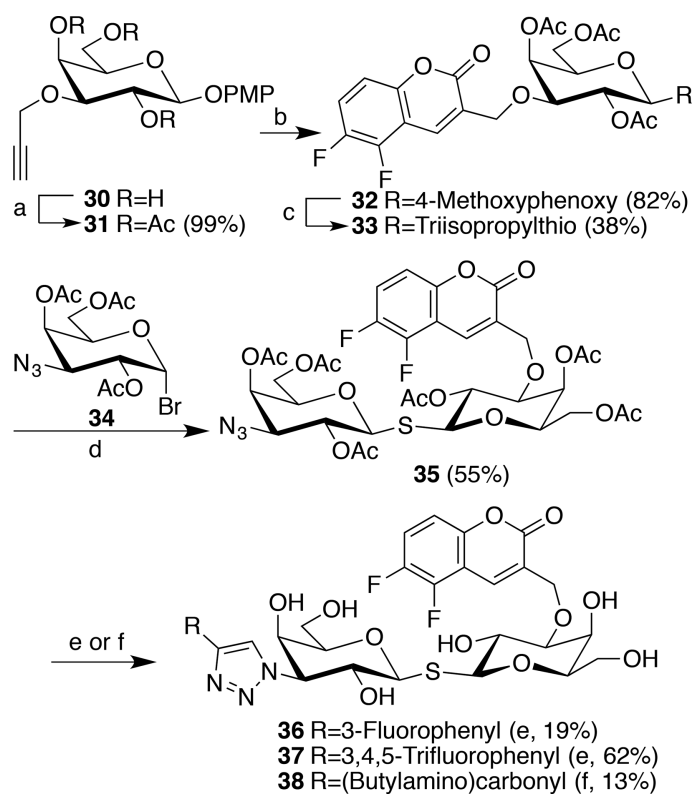

${ }^{a}$ Reagents and conditions: (a) $\mathrm{Ac}_{2} \mathrm{O}$, pyridine, rt; (b) (i) 5,6difluorosalicylaldehyde, CuI, $\mathrm{TsN}_{3}, \mathrm{Et}_{3} \mathrm{~N}$, THF, rt, 1 h, (ii) $\mathrm{NaOMe}$, $\mathrm{MeOH}$, rt, (iii) $\mathrm{Ac}_{2} \mathrm{O}$, pyridine, rt; (c) (i) $\mathrm{ZnBr}_{2}, \mathrm{AcBr}, \mathrm{CH}_{2} \mathrm{Cl}_{2}, \mathrm{rt}, 14$ $\mathrm{h}$, (ii) triisopropylsilanethiol, $\mathrm{K}_{2} \mathrm{CO}_{3}$, acetone, $\mathrm{rt}, 18 \mathrm{~h}$; (d) TBAF (1M in THF), MeCN, rt, $3 \mathrm{~h}$; (e) (i) alkyne, CuI, $\mathrm{Et}_{3} \mathrm{~N}$ or DIPEA, MeCN or DMF, $50{ }^{\circ} \mathrm{C}$, (ii) $\mathrm{NaOMe}, \mathrm{MeOH}, \mathrm{CH}_{2} \mathrm{Cl}_{2}$, rt; (f) (i) methyl propiolate, CuI, DIPEA, $\mathrm{MeCN}, 50{ }^{\circ} \mathrm{C}, 29 \mathrm{hm}$ (ii) $\mathrm{BuNH}_{2}, \mathrm{MeOH}$, rt.

side 23 with methyl propiolate in a 1,3-dipolar cycloaddition and subsequent deacetylation with butylamine in methanol.

Scheme 5. Synthesis of Asymmetrical Thiodigalactoside $39^{a}$

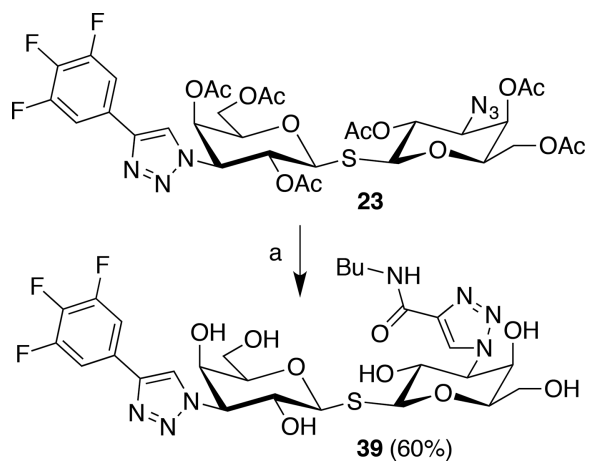

${ }^{a}$ Reagents and conditions: (a) (i) methyl propiolate, CuI, DIPEA, $\mathrm{MeCN}, 50{ }^{\circ} \mathrm{C}, 54$ h, (ii) $\mathrm{BuNH}_{2}, \mathrm{MeOH}$, rt.

The asymmetrical thiodigalactoside 36 , which can be viewed as a combination of compounds $\mathbf{1}$ and $\mathbf{2 8}$, inhibited galectin-3 5 -fold better than the bis-coumaryl derivative $\mathbf{2 8}$ and had about 20 -fold selectivity for galectin-3 over galectin-1 (Table 3 ). With additional fluorination on the phenyltriazole (37), the galectin3 affinity increased slightly and the selectivity for galectin- 3 over galectin-1 was improved to almost 50 -fold. The asymmetrical thiodigalactosides 38 and 39 both had high affinity for galectin3 and 14- and 26-fold selectivity, respectively, for galectin-3 over galectin-1. Hence, through combination of different structural features of the symmetrical thiodigalactosides 1-2, 19-21, and 28-29 into asymmetrical thiodigalactosides (36- 
Table 3. $K_{\mathrm{d}}(\mathrm{nM})$ Values for Asymmetrical

Thiodigalacosides 36-39 Determined by Competitive Fluorescence Polarization

\begin{tabular}{cccc} 
& galectin-1 & galectin-3 & galectin-1/galectin-3 \\
36 & $260 \pm 20$ & $12 \pm 1$ & 21 \\
37 & $340 \pm 20$ & $7.5 \pm 0.7$ & 46 \\
38 & $660 \pm 50$ & $47 \pm 3$ & 14 \\
39 & $63 \pm 7$ & $2.4 \pm 0.2$ & 26 \\
\hline
\end{tabular}

39), we were able to improve galectin-3 selectivity, while still maintaining single-digit nM galectin-3 affinity (37). Compound 37 displays a selectivity similar to the symmetrical dicoumarylmethyl 28 but with an affinity improved almost 8-fold.

Thermodynamic Analysis. Aiming at deeper understanding of the fundamental factors underlying ligandgalectin-3 interactions, we performed isothermal titration microcalorimetry (ITC) experiments with compounds 1-2, 19-21, 36-37, and 39. When directly titrating the meta-fluoro derivative 1 into galectin-3C (Figure 3A) the slope of the resulting titration curve was very steep, which resulted in large errors in estimation of the thermodynamic parameters obtained from the slope of the curve, such as $K_{\mathrm{d}}$ and entropy. Hence, we decided to develop a competitive ITC method in which a highaffinity ligand, such as $\mathbf{1}$, is titrated into a solution of a preformed complex between galectin-3C and a medium-affinity ligand (Figure 3B). We anticipated that a thiodisaccharide ligand carrying only one fluorophenyl-triazole group would possess attenuated affinity and that the affinity could be further attenuated if the fluorine was positioned ortho (cf. compound 6 with 7-8 in Table 1), as this was reported earlier to lower affinity for galectin-3 somewhat. ${ }^{28}$ Furthermore, to ensure that the ortho-fluorophenyl-triazole group interacted in only one ligand pose, we decided to substitute a galactosylthioglucoside with the ortho-fluorophenyltriazole group at the galactose C3. This will ensure that the monosaccharide residue (the galactose) carrying the phenyltriazole binds in the conserved galactose site and thus positions the phenyltriazole near R144, and in addition, the disaccharide structure would confer water solubility enough for the high concentration experiments required in ITC experiments. Hence, the galactosylthioglucoside 43 was synthesized by a $S$-glycosylation of the thiogalactoside donor $\mathbf{4 0}^{37}$ and the glucoside acceptor $\mathbf{4 1}$ facilitated by tetrabutylammonium fluoride followed by de-O-acetylation to give galactosylthioglucoside $\mathbf{4 2}$ and a subsequent 1,3-dipolar cycloaddition with 2-fluorophenylacetylene (Scheme 6).

Titration experiments were performed with the C-terminal domain of galectin-3 (galectin-3C) in order to minimize the risk of galectin-3 oligomerization under the experimental conditions. Data with 43 from both the competitive fluorescence anisotropy assay (galectin-3C $K_{d}=2.14 \pm 0.01$ $\mu \mathrm{M})$ and from direct ITC $\left(K_{\mathrm{d}}=7.4 \mu \mathrm{M}\right.$ with an asymmetric $68 \%$ confidence interval of $6.6-8.7 \mu \mathrm{M})$ confirmed that 43 indeed had a medium affinity for galectin-3C. Furthermore, compound 43 also bound with a significant enthalpic contribution $(\Delta H=-42.6 \mathrm{~kJ} / \mathrm{mol}$ and $-T \Delta S=13.2 \mathrm{~kJ} / \mathrm{mol})$.

The dissociation constants determined by competitive ITC fall in the low nanomolar range for all ligands, in agreement with competitive fluorescence polarization experiments with galectin-3C, however with somewhat higher values obtained by ITC for compounds 1-2, 37, and 39 (Table 4 and Figure 4). Of note, the dissociation constants for galectin-3C obtained with the fluorescence polarization assay are very similar to those
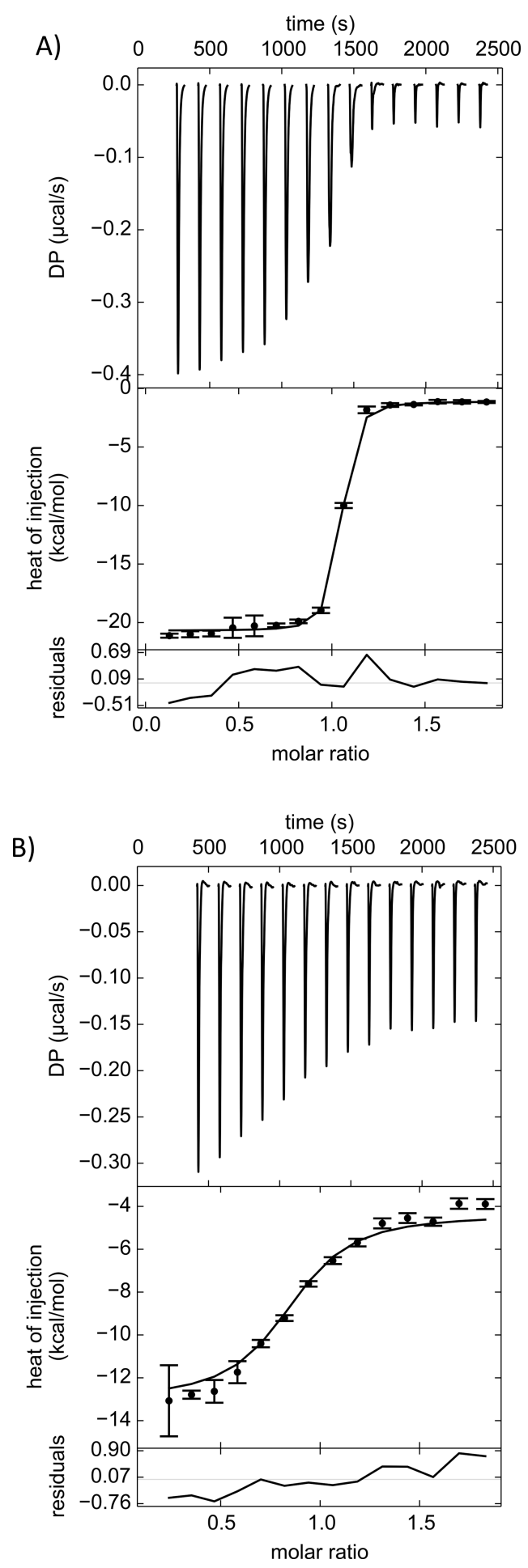

Figure 3. (A) Direct ITC with 1 and galectin-3 C-terminal domain revealing a step titration slope indicative of high affinity and providing lower accuracy extraction of binding parameters. (B) Competitive ITC with 1 to a galectin-3 C-terminal domain bound to 43 revealing a sigmoidal titration curve allowing for accurate extraction of binding parameters.

obtained with intact galectin-3, demonstrating that the ligand binding properties of galectin-3C are essentially identical to those of galectin-3. The competitive ITC experiments, however, show that thiodigalactosides 19-21 have higher galectin-3C affinity than thiodigalactosides 1-2, 37, and 39. Still, 
Scheme 6. Synthesis of a Galactosylthioglucoside 43 with an ortho-Fluorophenyltriazole Group at the Galactose $\mathrm{C3}^{a}$
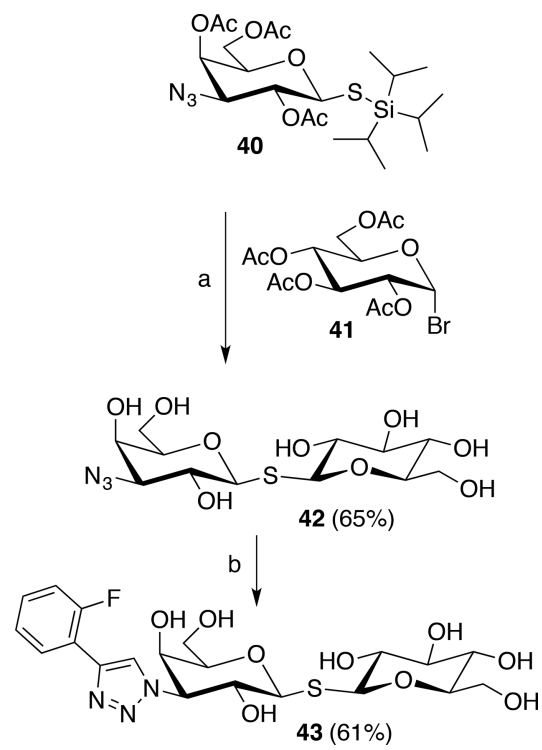

${ }^{a}$ Reagents and conditions: (a) (i) TBAF ( $1 \mathrm{M}$ in THF), MeCN, rt, $1 \mathrm{~h}$, (ii) $\mathrm{NaOMe}, \mathrm{MeOH}, \mathrm{rt}, 24 \mathrm{~h}$; (b) 2-fluorophenylacetylene, CuI, DIPEA, MeCN, $50^{\circ} \mathrm{C}, 24 \mathrm{~h}$.

differentiating between thiodigalactosides 19-21 is difficult, even with competitive ITC, and further analysis of these very high affinity galectin-3 ligands would be required in order to accurately determine their binding.

For all ligands, the ITC experiments provide clear evidence that the binding is driven by a large enthalpic contribution and has a significant, unfavorable entropy term. A para-fluorosubstituent on the phenyl moiety (2) is more enthalpically favorable than the corresponding meta-fluoro derivative 1, but this is counteracted by a more unfavorable entropic term. The same trend is seen in comparing the two tetrafluorinated compounds, where the meta-para-difluoro compound 19 shows an enthalpically more favorable binding than the meta-meta-difluoro compound 20. Interestingly, the hexafluorinated compound $\mathbf{2 1}$ has enthalpic and entropic terms that are intermediate between those of $\mathbf{1 9}$ and 20. The asymmetrical 3,4,5-trifluorophenyl coumaryl derivative 37 has a higher affinity than the asymmetrical 3-fluorophenyl coumaryl derivative 36 , mainly due to a significantly more favorable enthalpic term. The bis-triazolyl thiodigalactoside 39 is

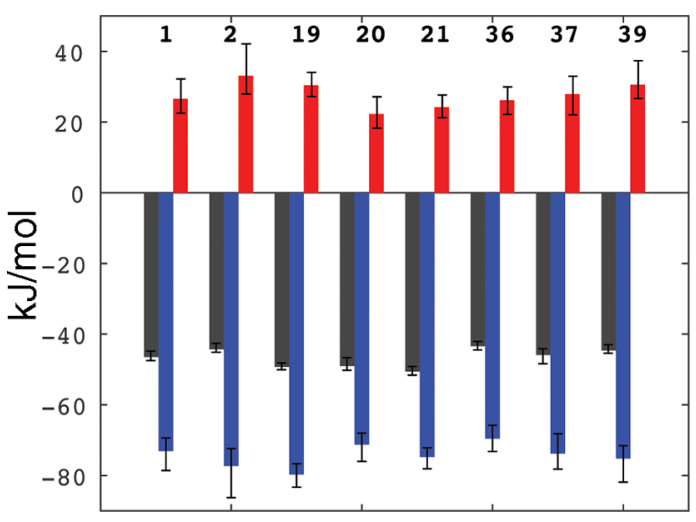

Figure 4. Thermodynamic parameters, $\Delta G$ (black bars), $\Delta H$ (blue bars), and $-T \Delta S$ (red bars), of 1-2, 19-21, 36-37, and 39 as determined in competitive ITC experiments with 43.

asymmetrical carrying one trifluorophenyl and one butylamide moiety on each of the triazole rings. Compounds 21 and 39 show similar favorable enthalpic terms, but 39 has a larger unfavorable entropic term, possibly due to galectin-3-complexation attenuating the flexibility of the butyl chain of 39 . We note that this series of ligand-galectin-3C complexes exhibit a general trend of enthalpy-entropy compensation.

Structural Analysis of Galectin-3C in Complex with 36 and 37. X-ray structures were obtained for two asymmetrical thiodigalactosides, the 3-fluorophenyl coumaryl 36 and the 3,4,5-trifluorophenyl coumaryl 37, in complex with galectin-3C. The refined X-ray structures (1.2 and $1.15 \AA$ resolution, respectively, Table $S 1$ in the Supporting Information) reveal split occupancy of ligand 36 but single occupancy of ligand 37 (Figures 5 and 6) within the galectin binding site. Hence, in the case of 36, the monofluorophenyl and difluorocoumaryl moieties apparently form approximately equally favorable interactions near R144 and near R186, while in the case of 37 , an improved interaction of a trifluorophenyl moiety near R144 drives the selection of one ligand pose, with the trifluorophenyl group residing between R144 and the galectin-3C backbone. The improved interaction of the trifluorophenyl group of 37 near R144 can be explained by three simultaneous orthogonal multipolar fluorine interactions with the carbonyl groups of R144, I145, and G238 (Figure 6B) in analogy to what has earlier been described separately for the monofluorinated phenyltriazoles 1 and $2 .^{28}$ The interpretation that the trifluorophenyl moiety of 37 forms more favorable interactions near R144 is also consistent with the trifluorinated

Table 4. Thermodynamic Parameters of Galectin-3C Binding 1-2, 19-21, 36-37, and 39 As Determined in Competitive ITC Experiments with $43^{a}$

\begin{tabular}{|c|c|c|c|c|c|}
\hline & $\Delta H(\mathrm{~kJ} / \mathrm{mol})$ & $-T \Delta S(\mathrm{~kJ} / \mathrm{mol})$ & $\Delta G(\mathrm{~kJ} / \mathrm{mol})$ & $K_{\mathrm{d}}(\mathrm{nM})^{b}$ & $K_{\mathrm{d}}(\mathrm{nM})^{c}$ \\
\hline 1 & $-73.1(-78.6,-69.4)$ & $26.6(21.0,30.7)$ & $-46.5(-47.5,-44.8)$ & $8.7(5.2,15)$ & $2.3 \pm 0.2$ \\
\hline 2 & $-77.3(-86.3,-72.4)$ & $33.1(24.1,38.3)$ & $-44.3(-45.2,-42.6)$ & $21(14,35)$ & $2.7 \pm 0.3$ \\
\hline 19 & $-79.7(-83.3,-76.7)$ & $30.4(26.7,33.6)$ & $-49.3(-50.1,-48.2)$ & $2.9(1.9,4.2)$ & $<1$ \\
\hline 20 & $-71.3(-76.0,-68.0)$ & $22.3(17.4,26.4)$ & $-49.0(-50.3,-46.7)$ & $3.2(1.6,6.1)$ & $<1$ \\
\hline 21 & $-74.8(-78.1,-72.2)$ & $24.2(20.8,27.2)$ & $-50.6(-51.6,-49.1)$ & $1.7(1.0,2.7)$ & $<1$ \\
\hline 36 & $-69.6(-73.2,-65.8)$ & $26.2(22.4,30.2)$ & $-43.4(-44.5,-42.1)$ & $30(16,45)$ & $27 \pm 3$ \\
\hline 39 & $-75.2(-81.9,-71.6)$ & $30.6(23.8,34.5)$ & $-44.6(-45.4,-43.0)$ & $19(13,31)$ & $15 \pm 0.4$ \\
\hline
\end{tabular}

${ }^{a}$ Errors in parentheses showing a $68 \%$ confidence interval, the first value is the upper confidence limit and the second is the lower. $K_{\mathrm{d}}$ values against galectin-3C determined with competitive fluorescence polarization are included for comparison. ${ }^{b} K_{\mathrm{d}}$ measured with competitive ITC. ${ }^{c} K_{\mathrm{d}}$ (galectin3C) measured with competitive fluorescence polarization using fluorescent probe molecule 26. 


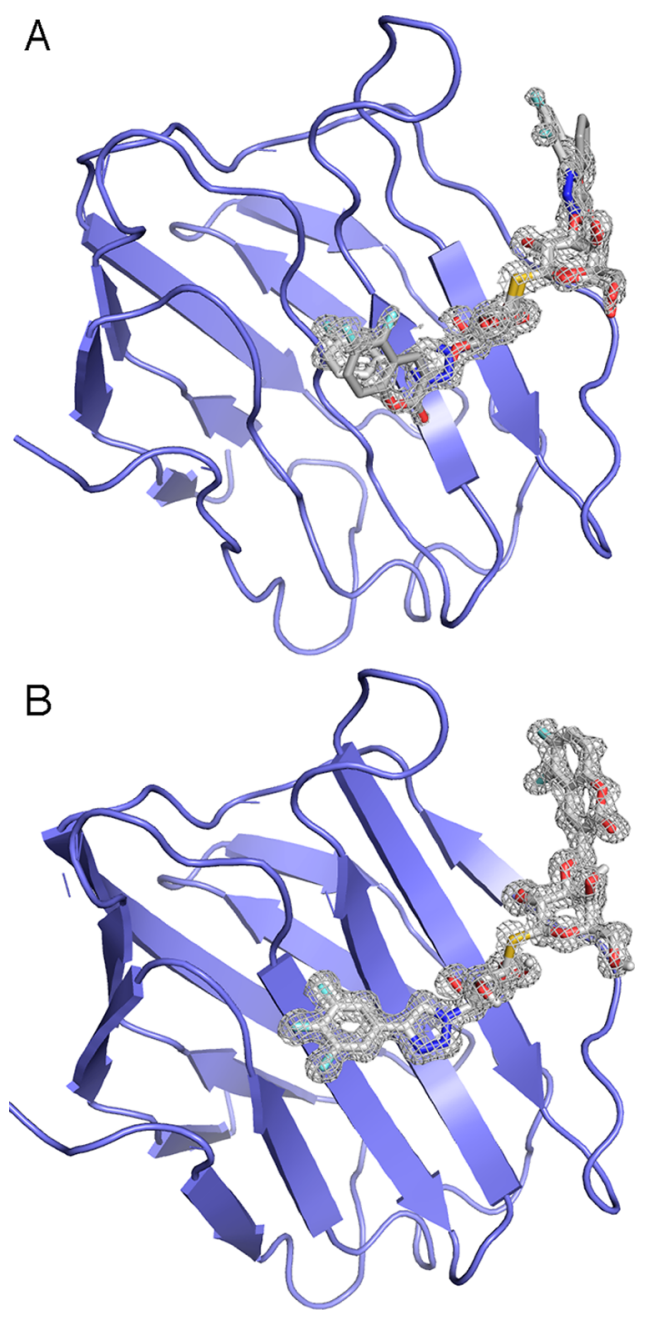

Figure 5. (A) Electron density map (gray mesh) with coefficients $2 \mathrm{ml}$ $F_{\mathrm{o}}|-D| F_{\mathrm{c}} \mid$ contoured at $1 \sigma$ for compound 36 in complex with galectin-3C reveals a split occupancy of the two possible thiodigalactoside orientations (dark- and light-gray carbon atoms, respectively). (B) Electron density map (gray mesh) with coefficients $2 m\left|F_{o}\right|-D\left|F_{c}\right|$ contoured at $1 \sigma$ for compound 37 in complex with galectin-3C, showing a single conformation with full occupancy.

monosaccharide 11 showing 4-fold improved affinity over the monofluorinated monosaccharide 7 .

\section{CONCLUSIONS}

A series of C3-aryltriazolyl-substituted thiogalactosides and a series of symmetrical C3-aryltriazolyl-substituted thiodigalactosides were synthesized to optimize binding near R144 of galectin-3. This led to the discovery of very high affinity $\left(K_{\mathrm{d}}\right.$ down to $1-2 \mathrm{nM}$ ) galectin-3 inhibitors as determined in two highly sensitive competitive titration assays with fluorescence anisotropy and isothermal titration calorimetry. Bis-O3coumaryl thiodigalactosides are highly galectin-3-selective and combining C3-aryltriazolyl groups with an O3-coumaryl into asymmetrical thiodigalactosides led to the discovery of galectin3 inhibitors with unsurpassed galectin-3 affinity and selectivity. Furthermore, structural analysis of two asymmetrical thiodigalactosides revealed that increased fluorination of a phenyl triazole group favored interactions near R144. The thermodynamic profiles of the thiodigalactoside derivatives binding to galectin-3C were determined by competitive ITC experiments

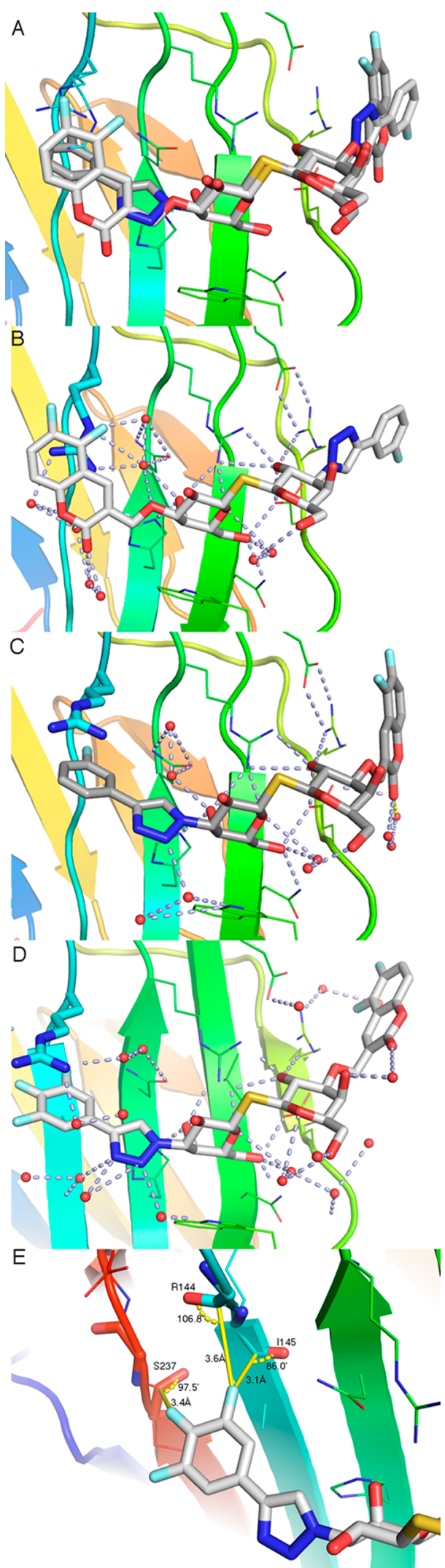

Figure 6. Galectin-3C in complex with compound 36 showing the (A) two interaction poses overlaid and then as separate figures in $\mathrm{B}$ and $\mathrm{C}$ with R144 side chain in sticks representation and including water molecules and polar contacts. (D) Galectin-3C in complex with compound 37. The R144 side chain atop on the trifluorophenyl is omitted for clarity. (E) Close-up view shows the fluorine interactions with carbonyl groups of residues R144, I145, and S237. 
to be driven by a large enthalpic contribution while having a significant unfavorable entropy term.

\section{EXPERIMENTAL SECTION}

General. All reagents and solvents were dried prior to use according to standard methods. Commercial reagents were used without further purification. Analytical TLC was performed using on silica gel $60 \mathrm{~F}_{254}$ (Merck) with detection by UV absorption and/or by charring following immersion in a $7 \%$ ethanolic solution of sulfuric acid. Purification of compounds was carried out by column chromatography on silica gel $(40-60 \mu \mathrm{m}, 60 \AA)$ and/or preparative HPLC (Agilent 1260 infinity system, column SymmetryPrep-C18, 17 $\mathrm{mL} / \mathrm{min} \mathrm{H}_{2} \mathrm{O}-\mathrm{MeCN}$ gradient $10-100 \% 15$ min with $0.1 \%$ formic acid). Specific rotations were measured on a PerkinElmer model 341 polarimeter. NMR spectra ${ }^{1} \mathrm{H},{ }^{13} \mathrm{C}, 2 \mathrm{D}$ COSY, and HMQC were recorded with a Bruker Avance II $400 \mathrm{MHz}$ spectrometer $(400 \mathrm{~Hz}$ for ${ }^{1} \mathrm{H}, 100 \mathrm{~Hz}$ for ${ }^{13} \mathrm{C}$ ) at ambient temperature. Chemical shifts are reported in $\delta$ parts per million (ppm). HRMS was determined by direct infusion on a Waters XEVO-G2 QTOF mass spectrometer using electrospray ionization (ESI). Compounds 5-17, 19-21, 25$26,36-39$, and 43 were of $>95 \%$ purity according to HPLC-analysis (Agilent series 1100 system, column Eclipse XDB-C18, $0.8 \mathrm{~mL} / \mathrm{min}$ $\mathrm{H}_{2} \mathrm{O}-\mathrm{MeCN}$ gradient $5-95 \% 13 \mathrm{~min}$ with $0.1 \%$ TFA) or UPLC (Waters Acquity UPLC system, column Waters Acquity CSH C18, 0.5 $\mathrm{mL} / \mathrm{min} \mathrm{H}_{2} \mathrm{O}-\mathrm{MeCN}$ gradient $5-95 \% 10$ min with $0.1 \%$ formic acid) analysis. Fluorescent molecules 25-26 show spectral properties close to their unsubstituted fluorophores. Detailed synthetic procedures, with analytical data, for intermediates $(4,22-24,31-33,35$, and 42$)$ and low potency inhibitors (5-16 and 43) can be found in the Supporting Information.

General Procedure for Preparation of Triazoles (19-21). To a solution of compound $18(30 \mathrm{mg}, 0.045 \mathrm{mmol})$ and $\mathrm{CuI}(4 \mathrm{mg}$, $0.023 \mathrm{mmol})$ in DMF $(3 \mathrm{~mL})$ were the corresponding acetylene derivative ( $x, 3$ equiv) and DIPEA $(16 \mu \mathrm{L}, 0.091 \mathrm{mmol})$ added. The mixture was stirred $(t) \mathrm{h}$ at $50{ }^{\circ} \mathrm{C}$ before quenching with satd aq $\mathrm{NH}_{4} \mathrm{Cl}$ followed by evaporation of the solvent. The residue was extracted twice with EtOAc, and the organic phases were washed with brine, dried, and evaporated. The obtained crude product was dissolved in $\mathrm{MeOH}(3 \mathrm{~mL})$ and DCM $(1 \mathrm{~mL})$ followed by addition of $\mathrm{NaOMe}(1 \mathrm{M}, 1 \mathrm{~mL})$, and the resulting solution was stirred overnight. After neutralization with Dowex 50W-X8 $\left(\mathrm{H}^{+}\right)$resin and filtration, the product was purified with column chromatography (DCM:MeOH 19:1 $\rightarrow$ 9:1) to give an amorphous white solid.

1,1'-Sulfanediyl-bis-\{3-deoxy-3-[4-(3,4-difluorophenyl)- $1 \mathrm{H}-1,2,3-$ triazol-1-yl]- $\beta$-D-galactopyranoside\} 19. $x=3$,4-difluorophenylacetylene, $t=27 \mathrm{~h}$. Yield $28 \mathrm{mg}, 91 \%$. $[\alpha]_{\mathrm{D}}{ }^{20} 7.1\left(c 0.85, \mathrm{CH}_{3} \mathrm{OH}\right) .{ }^{1} \mathrm{H}$ NMR ( $\left.\mathrm{CD}_{3} \mathrm{OD}, 400 \mathrm{MHz}\right): \delta 8.56(\mathrm{~s}, 2 \mathrm{H}, \mathrm{Ph}), 7.73$ (ddd, $J=11.6$, $7.7,2.1 \mathrm{~Hz}, 2 \mathrm{H}, \mathrm{Ph}), 7.61(\mathrm{~m}, 2 \mathrm{H}, \mathrm{Ph}), 7.31(\mathrm{dt}, J=10.4,8.5 \mathrm{~Hz}, 2 \mathrm{H}$, $\mathrm{Ph}), 4.91(\mathrm{~m}, 4 \mathrm{H}, \mathrm{H}-1$ and $\mathrm{H}-3), 4.80(\mathrm{t}, J=10.0 \mathrm{~Hz}, 2 \mathrm{H}, \mathrm{H}-2), 4.17$ $(\mathrm{d}, J=2.7 \mathrm{~Hz}, 2 \mathrm{H}, \mathrm{H}-4), 3.92-3.81(\mathrm{~m}, 4 \mathrm{H}, \mathrm{H}-5$ and $\mathrm{H}-6), 3.72(\mathrm{dd}, J$ $=11.4,4.5 \mathrm{~Hz}, 2 \mathrm{H}, \mathrm{H}-6) .{ }^{13} \mathrm{C}$ NMR $\left(\mathrm{CD}_{3} \mathrm{OD}, 100 \mathrm{MHz}\right): \delta 153.1$, $152.5,150.7,150.1,146.4,139.2,129.5,123.1,122.3,118.9,115.4$, $86.7,81.4,69.7,68.8,68.4,62.8$. HRMS calculated for $\left[\mathrm{C}_{28} \mathrm{H}_{29} \mathrm{~F}_{4} \mathrm{~N}_{6} \mathrm{O}_{8} \mathrm{~S}\right]^{+}$685.1704, found 685.1696.

1,1'-Sulfanediyl-bis-\{3-deoxy-3-[4-(3,5-difluorophenyl)-1H-1,2,3triazol-1-yl]- $\beta$-D-galactopyranoside\} 20. $x=3,5$-difluorophenylacetylene, $t=22 \mathrm{~h}$. Yield $27 \mathrm{mg}, 88 \%$. $[\alpha]_{\mathrm{D}}{ }^{20} 15.4\left(c 1.24, \mathrm{CH}_{3} \mathrm{OH}\right) .{ }^{1} \mathrm{H}$ NMR $\left(\mathrm{CD}_{3} \mathrm{OD}, 400 \mathrm{MHz}\right): \delta 8.62(\mathrm{~s}, 2 \mathrm{H}, \mathrm{Ph}), 7.45(\mathrm{~d}, J=7.8 \mathrm{~Hz}$, $4 \mathrm{H}, \mathrm{Ph}), 6.91(\mathrm{tt}, J=9.2,2.3 \mathrm{~Hz}, 2 \mathrm{H}, \mathrm{Ph}), 4.93(\mathrm{~m}, 4 \mathrm{H}, \mathrm{H}-1$ and $\mathrm{H}-3)$, $4.71(\mathrm{t}, J=10.0 \mathrm{~Hz}, 2 \mathrm{H}, \mathrm{H}-2), 4.17(\mathrm{~d}, J=2.7 \mathrm{~Hz}, 2 \mathrm{H}, \mathrm{H}-4), 3.92-$ $3.82(\mathrm{~m}, 4 \mathrm{H}, \mathrm{H}-5$ and $\mathrm{H}-6), 3.73(\mathrm{dd}, J=11.4,4.5 \mathrm{~Hz}, 2 \mathrm{H}, \mathrm{H}-6) .{ }^{13} \mathrm{C}$ NMR ( $\left.\mathrm{CD}_{3} \mathrm{OD}, 100 \mathrm{MHz}\right): \delta 166.2,163.7,146.3,135.6,122.9,109.3$, 104.0, 86.6, 81.4, 69.7, 68.9, 68.4, 62.8. HRMS calculated for $\left[\mathrm{C}_{28} \mathrm{H}_{29} \mathrm{~F}_{4} \mathrm{~N}_{6} \mathrm{O}_{8} \mathrm{~S}\right]^{+}$685.1704, found 685.1714.

1, 1'-Sulfanediyl-bis-\{3-deoxy-3-[4-(3,4,5-trifluorophenyl)- $1 \mathrm{H}$ 1,2,3-triazol-1-yl]- $\beta$-D-galactopyranoside\} 21. $x=3,4,5$-trifluorophenylacetylene, $t=22 \mathrm{~h}$. Yield $25 \mathrm{mg}, 77 \%$. $[\alpha]_{\mathrm{D}}{ }^{20} 15.1$ (c 1.30 , $\left.\mathrm{CH}_{3} \mathrm{OH}\right) .{ }^{1} \mathrm{H}$ NMR ( $\left.\mathrm{CD}_{3} \mathrm{OD}, 400 \mathrm{MHz}\right): \delta 8.59$ (s, $\left.2 \mathrm{H}, \mathrm{Ph}\right), 7.60$ (dd, $J=8.8,6.6 \mathrm{~Hz}, 4 \mathrm{H}, \mathrm{Ph}), 4.94$ (d, $J=9.6 \mathrm{~Hz}, 2 \mathrm{H}, \mathrm{H}-1) 4.92$ (dd, $J$
$=10.6,3.0,2 \mathrm{H}, \mathrm{H}-3), 4.71(\mathrm{t}, J=10.0 \mathrm{~Hz}, 2 \mathrm{H}, \mathrm{H}-2), 4.17(\mathrm{~d}, J=3.0$ $\mathrm{Hz}, 2 \mathrm{H}, \mathrm{H}-4), 3.92-3.81$ (m, 4H, H-5 and H-6), 3.72 (dd, $J=11.4,4.5$ $\mathrm{Hz}, 2 \mathrm{H}, \mathrm{H}-6) .{ }^{13} \mathrm{C}$ NMR $\left(\mathrm{CD}_{3} \mathrm{OD}, 100 \mathrm{MHz}\right): \delta 154.1,151.6,145.5$, $141.7,139.2,128.9,122.8,110.7,86.5,81.3,69.7,68.9,68.4,62.8$. HRMS calculated for $\left[\mathrm{C}_{28} \mathrm{H}_{27} \mathrm{~F}_{6} \mathrm{~N}_{6} \mathrm{O}_{8} \mathrm{~S}\right]^{+} 721.1515$, found 721.1514.

General Procedure for Preparation of Fluorescent Molecules (25-26). To a solution of FAM alkyne 5-isomer (1.1 equiv), $\mathrm{CuI}$ (0.5 equiv), and 22 (11.6 mg, $0.022 \mathrm{mmol})$ for 25 or $24(12.4 \mathrm{mg}$, $0.022 \mathrm{mmol}$ ) for 26 , in dry DMF ( $3 \mathrm{~mL}$ ) DIPEA (2 equiv) was added and the mixture was stirred $24 \mathrm{~h}$ at $50{ }^{\circ} \mathrm{C}$. The reaction was quenched with satd aq $\mathrm{NH}_{4} \mathrm{Cl}$ followed by purification with preparative HPLC to give an amorphous yellow solid.

3,3'-Dideoxy-3-[4-(fluorescein-5-yl-carbonylaminomethyl)- $1 \mathrm{H}$ 1,2,3-triazol-1-yl]-3'-[4-(3-fluorophenyl)-1H-1,2,3-triazol-1-yl]-1,1'sulfanediyl-di- $\beta$-D-galactopyranoside 25 . Yield $15.9 \mathrm{mg}, 77 \% .{ }^{1} \mathrm{H}$ NMR ( $\left.\mathrm{CD}_{3} \mathrm{OD}, 400 \mathrm{MHz}\right): \delta 8.56(\mathrm{~s}, 1 \mathrm{H}, \mathrm{Ph}), 8.44(\mathrm{~s}, 1 \mathrm{H}, \mathrm{Ph}), 8.20$ $(\mathrm{m}, 2 \mathrm{H}, \mathrm{Ph}), 7.62(\mathrm{dt}, J=7.9,1.1 \mathrm{~Hz}, 1 \mathrm{H}, \mathrm{Ph}), 7.56(\mathrm{ddd}, J=10.1,2.5$, $1.5 \mathrm{~Hz}, 1 \mathrm{H}, \mathrm{Ph}), 7.41(\mathrm{~m}, 1 \mathrm{H}, \mathrm{Ph}), 7.25(\mathrm{~d}, J=8.1 \mathrm{~Hz}, 1 \mathrm{H}, \mathrm{Ph}), 7.04$ (tdd, $J=8.5,2.5,0.9 \mathrm{~Hz}, 1 \mathrm{H}, \mathrm{Ph}), 6.68(\mathrm{~d}, J=2.3 \mathrm{~Hz}, 2 \mathrm{H}, \mathrm{Ph}), 6.57$ (dd, $J=8.7,3.8 \mathrm{~Hz}, 2 \mathrm{H}, \mathrm{Ph}$ ), 6.52 (ddd, $J=8.7,2.3,1.3 \mathrm{~Hz}, 2 \mathrm{H}, \mathrm{Ph}$ ), 4.87 (obscured by water, $\mathrm{H} 1, \mathrm{H}-1^{\prime}, \mathrm{H}-3$ and $\left.\mathrm{H}-3^{\prime}\right), 4.80-4.69(\mathrm{~m}, 4 \mathrm{H}$, $\mathrm{CH}_{2}, \mathrm{H}-2$ and $\left.\mathrm{H}-2^{\prime}\right), 4.15\left(\mathrm{~d}, J=2.8 \mathrm{~Hz}, 1 \mathrm{H}, \mathrm{H}-4\right.$ or $\left.\mathrm{H}-4^{\prime}\right), 4.13(\mathrm{~d}, J$ $=2.5 \mathrm{~Hz}, 1 \mathrm{H}, \mathrm{H}-4$ or $\left.\mathrm{H}-4^{\prime}\right), 3.88-3.76(\mathrm{~m}, 4 \mathrm{H}, \mathrm{H}-5$ and $\mathrm{H}-6), 3.72-$ $3.63(\mathrm{~m}, 2 \mathrm{H}, \mathrm{H}-6) .{ }^{13} \mathrm{C} \mathrm{NMR}\left(\mathrm{CD}_{3} \mathrm{OD}, 100 \mathrm{MHz}\right): \delta 170.6,168.4$, $165.9,163.4,161.5,154.0,147.2$, 137.4, 135.5, 134.3, 131.9, 130.2, $125.7,125.0,124.3,122.5,115.8,113.8,113.1,110.8,103.6,86.7,81.4$, $69.8,69.7,68.8,68.4,68.3,62.9,62.8,36.5$. HRMS calculated for $\left[\mathrm{C}_{44} \mathrm{H}_{41} \mathrm{FN}_{7} \mathrm{O}_{14} \mathrm{~S}\right]^{+}$942.2416, found 942.2417.

3,3'-Dideoxy-3-[4-(fluorescein-5-yl-carbonylaminomethyl)- $1 \mathrm{H}$ 1,2,3-triazol-1-yl]-3'-[4-(3,4,5-trifluorophenyl)-1H-1,2,3-triazol-1-yl]$1,1^{\prime}$-sulfanediyl-di- $\beta$-D-galactopyranoside 26 . Yield $10.7 \mathrm{mg}, 50 \%$. $[\alpha]_{\mathrm{D}}{ }^{20} 16.7\left(c 0.89, \mathrm{CH}_{3} \mathrm{OH}\right) .{ }^{1} \mathrm{H}$ NMR $\left(\mathrm{CD}_{3} \mathrm{OD}, 400 \mathrm{MHz}\right): \delta 8.57$ $(\mathrm{s}, 1 \mathrm{H}, \mathrm{Ph}), 8.44(\mathrm{~s}, 1 \mathrm{H}, \mathrm{Ph}), 8.20(\mathrm{~m}, 2 \mathrm{H}, \mathrm{Ph}), 7.59(\mathrm{dd}, J=8.4,6.7$ $\mathrm{Hz}, 2 \mathrm{H}, \mathrm{Ph}), 7.27(\mathrm{~d}, J=8.1 \mathrm{~Hz}, 1 \mathrm{H}, \mathrm{Ph}), 6.68(\mathrm{~d}, J=2.3 \mathrm{~Hz}, 2 \mathrm{H}, \mathrm{Ph})$, $6.60(\mathrm{dd}, J=8.7,1.2 \mathrm{~Hz}, 2 \mathrm{H}, \mathrm{Ph}), 6.53(\mathrm{dd}, J=8.7,2.2 \mathrm{~Hz}, 2 \mathrm{H}, \mathrm{Ph})$, 4.87 (obscured by water, $\mathrm{H} 1, \mathrm{H}-\mathrm{1}^{\prime}, \mathrm{H}-3$ and $\left.\mathrm{H}-3^{\prime}\right), 4.71\left(\mathrm{~m}, 4 \mathrm{H}, \mathrm{CH}_{2}\right.$, $\mathrm{H}-2$ and $\left.\mathrm{H}-2^{\prime}\right), 4.17\left(\mathrm{t}, J=3.1 \mathrm{~Hz}, 2 \mathrm{H}, \mathrm{H}-4\right.$ and $\left.\mathrm{H}-4^{\prime}\right), 3.88-3.76(\mathrm{~m}$, $4 \mathrm{H}, \mathrm{H}-5$ and H-6), 3.71-3.63 (m, $2 \mathrm{H}, \mathrm{H}-6) .{ }^{13} \mathrm{C}$ NMR ( $\mathrm{CD}_{3} \mathrm{OD}, 100$ $\mathrm{MHz}): \delta 170.7,168.4,154.3,145.5,137.3,135.2,130.3,126.0,125.3$, $124.2,122.8,114.2,111.1,110.8,110.6,103.6,86.7,86.6,81.4,69.9$, $69.7,68.8,68.4,68.3,62.9,62.8,36.5$. HRMS calculated for $\left[\mathrm{C}_{44} \mathrm{H}_{39} \mathrm{~F}_{3} \mathrm{~N}_{7} \mathrm{O}_{14} \mathrm{~S}\right]^{+}$978.2228, found 978.2241.

3'-Deoxy-3-O-[(5,6-difluoro-2-oxo-2 H-chromene-3-yl)methyl]-3'-[4-(3-fluorophenyl)-1H-1,2,3-triazol-1-yl]-1,1'-sulfanediyl-di- $\beta$-D-galactopyranoside 36 . To a solution of compound 35 (169 mg, $0.20 \mathrm{mmol})$ and $\mathrm{CuI}(8 \mathrm{mg}, 0.041 \mathrm{mmol})$ in $\mathrm{MeCN}(10$ $\mathrm{mL})$ 3-fluorophenylacetylene $(0.052 \mathrm{~mL}, 0.45 \mathrm{mmol})$ was added followed by $\mathrm{Et}_{3} \mathrm{~N}(0.014 \mathrm{~mL}, 0.10 \mathrm{mmol})$, and the mixture was stirred at $50{ }^{\circ} \mathrm{C}$ for $18 \mathrm{~h}$ before quenching with satd aq $\mathrm{NH}_{4} \mathrm{Cl}$. The volatiles were evaporated and the obtained residue was extracted twice with EtOAc and the organic phases were washed with brine, dried, and evaporated. The obtained crude product was dissolved in $\mathrm{MeOH}(20$ $\mathrm{mL})$ and DCM $(3 \mathrm{~mL}), \mathrm{NaOMe}(1 \mathrm{M}, 10 \mathrm{~mL})$ was added, and the solution was stirred overnight. After neutralization with Dowex 50WX8 $\left(\mathrm{H}^{+}\right)$resin and filtration, the product was purified with column chromatography (DCM:MeOH 19:1 $\rightarrow$ 9:1) to give $36(27 \mathrm{mg}, 19 \%)$ as an amorphous white solid. $[\alpha]_{\mathrm{D}}{ }^{20} 36.4\left(c 0.69, \mathrm{CH}_{3} \mathrm{OH}\right) .{ }^{1} \mathrm{H}$ NMR $\left(\mathrm{CD}_{3} \mathrm{OD}, 400 \mathrm{MHz}\right): \delta 8.52(\mathrm{~s}, 1 \mathrm{H}, \mathrm{Ph}), 8.35(\mathrm{~s}, 1 \mathrm{H}, \mathrm{Ph}), 7.64(\mathrm{~d}, J=$ $7.7 \mathrm{~Hz}, 1 \mathrm{H}, \mathrm{Ph}), 7.57$ (d, $J=10.2 \mathrm{~Hz}, 1 \mathrm{H}, \mathrm{Ph}), 7.51-7.40(\mathrm{~m}, 2 \mathrm{H}$, $\mathrm{Ph}), 7.17(\mathrm{~d}, J=9.4 \mathrm{~Hz}, 1 \mathrm{H}, \mathrm{Ph}), 7.05(\mathrm{t}, J=8.5 \mathrm{~Hz}, 1 \mathrm{H}, \mathrm{Ph}), 4.97(\mathrm{~d}$, $\left.J=9.6 \mathrm{~Hz}, 1 \mathrm{H}, \mathrm{H}-1^{\prime}\right), 4.90$ (obscured by water $\left.\mathrm{H}-3^{\prime}\right), 4.80$ (d, $J=9.9$ $\mathrm{Hz}, 1 \mathrm{H}, \mathrm{H}-1), 4.72\left(\mathrm{~d}, J=15.6 \mathrm{~Hz}, 1 \mathrm{H}, \mathrm{CH}_{2}\right), 4.62(\mathrm{~d}, J=15.6 \mathrm{~Hz}$ $\left.1 \mathrm{H}, \mathrm{CH}_{2}\right), 4.44\left(\mathrm{t}, J=10.0 \mathrm{~Hz}, 1 \mathrm{H}, \mathrm{H}-2^{\prime}\right), 4.22(\mathrm{~d}, J=2.2 \mathrm{~Hz}, 1 \mathrm{H}, \mathrm{H}-$ 4), $4.15\left(\mathrm{~d}, J=2.2 \mathrm{~Hz}, 1 \mathrm{H}, \mathrm{H}-4^{\prime}\right), 3.96(\mathrm{t}, J=9.4 \mathrm{~Hz}, 1 \mathrm{H}, \mathrm{H}-2), 3.89-$ $3.80\left(\mathrm{~m}, 3 \mathrm{H}, \mathrm{H}-5^{\prime}\right.$ and $\left.\mathrm{H}-6\right), 3.76-3.64\left(\mathrm{~m}, 3 \mathrm{H}, \mathrm{H}-5\right.$ and $\left.\mathrm{H}-6^{\prime}\right), 3.53$ $(\mathrm{dd}, J=9.1,2.7 \mathrm{~Hz}, 1 \mathrm{H}, \mathrm{H}-3) .{ }^{13} \mathrm{C} \mathrm{NMR}\left(\mathrm{CD}_{3} \mathrm{OD}, 100 \mathrm{MHz}\right): \delta$ $165.8,163.4,161.1,150.2$, 148.8, 148.0, 147.1, 146.4, 145.4, 134.2, $132.0,131.9,129.0,122.5,122.4,120.4,115.8,113.4,113.1,112.0$, 86.2, 85.2, 84.7, 81.2, 80.8, 70.8, 69.7, 69.0, 68.5, 67.5, 67.1, 63.0, 62.6. 
HRMS calculated for $\left[\mathrm{C}_{30} \mathrm{H}_{30} \mathrm{~F}_{3} \mathrm{~N}_{3} \mathrm{O}_{11} \mathrm{SNa}\right]^{+}$720.1451, found 720.1443.

3'-Deoxy-3-O-[(5,6-difluoro-2-oxo-2 H-chromene-3-yl)methyl]-3'-[4-(3,4,5-trifluorophenyl)-1H-1,2,3-triazol-1-yl]-1,1'sulfanediyl-di- $\beta$-D-galactopyranoside 37 . To a solution of compound $35(20 \mathrm{mg}, 0.024 \mathrm{mmol})$ and $\mathrm{CuI}(1 \mathrm{mg}, 0.0060 \mathrm{mmol})$ in DMF (3 mL) 3,4,5-trifluorophenylacetylene $(0.005 \mathrm{~mL}, 0.036$ $\mathrm{mmol})$ was added followed by DIPEA $(0.004 \mathrm{~mL}, 0.024 \mathrm{mmol})$, and the mixture was stirred at $50{ }^{\circ} \mathrm{C}$ for $22 \mathrm{~h}$ before quenching with satd aq $\mathrm{NH}_{4} \mathrm{Cl}$. The volatiles were evaporated and the obtained residue was extracted twice with EtOAc and the organic phases were washed with brine, dried, and evaporated. The obtained crude product was dissolved in $\mathrm{MeOH}(3 \mathrm{~mL})$ and DCM $(1 \mathrm{~mL}), \mathrm{NaOMe}(1 \mathrm{M}, 1$ $\mathrm{mL}$ ) was added, and the solution was stirred overnight. After neutralization with Dowex 50W-X8 $\left(\mathrm{H}^{+}\right)$resin and filtration, the product was purified with column chromatography (DCM:MeOH 19:1 $\rightarrow$ 9:1) to give $37(11 \mathrm{mg}, 62 \%)$ as an amorphous white solid. $[\alpha]_{\mathrm{D}}{ }^{20} 31.1\left(c 0.61, \mathrm{CH}_{3} \mathrm{OH}\right) .{ }^{1} \mathrm{H}$ NMR $\left(\mathrm{CD}_{3} \mathrm{OD}, 400 \mathrm{MHz}\right): \delta 8.55$ $(\mathrm{s}, 1 \mathrm{H}, \mathrm{Ph}), 8.38(\mathrm{~s}, 1 \mathrm{H}, \mathrm{Ph}), 7.63(\mathrm{dd}, J=8.9,6.6 \mathrm{~Hz}, 2 \mathrm{H}, \mathrm{Ph}), 7.50$ $(\mathrm{q}, J=9.1 \mathrm{~Hz}, 1 \mathrm{H}, \mathrm{Ph}), 7.20(\mathrm{~d}, J=9.2 \mathrm{~Hz}, 1 \mathrm{H}, \mathrm{Ph}), 4.94(\mathrm{~d}, J=9.6$ $\mathrm{Hz}, 1 \mathrm{H}, \mathrm{H}-\mathrm{1}^{\prime}$ ), 4.88 (dd, $\left.J=9.8,3.0 \mathrm{~Hz}, 1 \mathrm{H}, \mathrm{H}-3^{\prime}\right), 4.77(\mathrm{~d}, J=9.9 \mathrm{~Hz}$, $1 \mathrm{H}, \mathrm{H}-1$ ), 4.73 (dd, $J=15.4,1.5 \mathrm{~Hz}, 1 \mathrm{H}, \mathrm{CH}_{2}$ ), 4.63 (dd, $J=15.4,1.5$ $\left.\mathrm{Hz}, 1 \mathrm{H}, \mathrm{CH}_{2}\right), 4.40\left(\mathrm{t}, J=9.6 \mathrm{~Hz}, 1 \mathrm{H}, \mathrm{H}-2^{\prime}\right), 4.22(\mathrm{~d}, J=2.7 \mathrm{~Hz}, 1 \mathrm{H}$, $\mathrm{H}-4), 4.12\left(\mathrm{~d}, J=2.8 \mathrm{~Hz}, 1 \mathrm{H}, \mathrm{H}-4^{\prime}\right), 3.96(\mathrm{t}, J=9.6 \mathrm{~Hz}, 1 \mathrm{H}, \mathrm{H}-2)$, 3.86-3.79 (m, 3H, H-5' and $\mathrm{H}-6), 3.75-3.67\left(\mathrm{~m}, 2 \mathrm{H}, \mathrm{H}-6^{\prime}\right), 3.64(\mathrm{~m}$, $1 \mathrm{H}, \mathrm{H}-5), 3.53(\mathrm{dd}, J=9.2,3.1 \mathrm{~Hz}, 1 \mathrm{H}, \mathrm{H}-3) .{ }^{13} \mathrm{C} \mathrm{NMR}\left(\mathrm{CD}_{3} \mathrm{OD}\right.$, $100 \mathrm{MHz}): \delta 161.0,145.5,132.0,129.1,122.9,120.4,113.4,110.9$, $110.6,86.2,85.3,84.7,81.2,80.8,70.8,69.7,69.1,68.5,67.6,67.2$, 63.0, 62.6. HRMS calculated for $\left[\mathrm{C}_{30} \mathrm{H}_{29} \mathrm{~F}_{5} \mathrm{~N}_{3} \mathrm{O}_{11} \mathrm{~S}\right]^{+}$734.1443, found 734.1453.

$3^{\prime}-\{4-[($ Butylamino)carbonyl]-1H-1,2,3-triazol-1-yl\}-3'-deoxy3-O-[(5,6-difluoro-2-oxo-2H-chromene-3-yl)methyl]-1,1'-sulfanediyl-di- $\beta$-D-galactopyranoside 38 . To a solution of compound $35(40 \mathrm{mg}, 0.048 \mathrm{mmol})$ and $\mathrm{CuI}(4.9 \mathrm{mg}, 0.026 \mathrm{mmol})$ in acetonitrile (3 $\mathrm{mL})$ methyl propiolate $(0.006 \mathrm{~mL}, 0.072 \mathrm{mmol})$ was added followed by DIPEA $(0.008 \mathrm{~mL}, 0.048 \mathrm{mmol})$, and the mixture was stirred at $50{ }^{\circ} \mathrm{C}$ for $29 \mathrm{~h}$ before quenching with satd aq $\mathrm{NH}_{4} \mathrm{Cl}$. The volatiles were evaporated and the obtained residue was extracted twice with EtOAc and the organic phases were washed with brine, dried, and evaporated. The obtained crude was stirred with a $4 \mathrm{~mL}$ solution of butylamine $20 \%$ in $\mathrm{MeOH}$ for $46 \mathrm{~h}$ at rt. The solution was evaporated and the residue was purified with flash chromatography (DCM:MeOH 19:1 $\rightarrow$ 9:1), but purification with preparative HPLC was needed to obtain pure $38(4.5 \mathrm{mg}, 13 \%)$ as an amorphous white solid. $[\alpha]_{\mathrm{D}}{ }^{20}$ 34.3 (c $\left.0.28, \mathrm{CH}_{3} \mathrm{OH}\right) .{ }^{1} \mathrm{H}$ NMR $\left(\mathrm{CD}_{3} \mathrm{OD}, 400 \mathrm{MHz}\right): \delta 8.47(\mathrm{~s}, 1 \mathrm{H}$, $\mathrm{Ph}), 8.39(\mathrm{~s}, 1 \mathrm{H}, \mathrm{Ph}), 7.51(\mathrm{q}, J=9.2 \mathrm{~Hz}, 1 \mathrm{H}, \mathrm{Ph}), 7.21(\mathrm{~d}, J=9.2 \mathrm{~Hz}$, $1 \mathrm{H}, \mathrm{Ph}$ ), 4.92 (obscured by water $\mathrm{H}-\mathrm{1}^{\prime}$ ), 4.89 (obscured by water $\mathrm{H}$ $\left.3^{\prime}\right), 4.77(\mathrm{~d}, J=10.0 \mathrm{~Hz}, 1 \mathrm{H}, \mathrm{H}-1), 4.73(\mathrm{dd}, J=15.4,1.5 \mathrm{~Hz}, 1 \mathrm{H}$, $\mathrm{CH}_{2}$ ), $4.63\left(\mathrm{dd}, J=15.4,1.5 \mathrm{~Hz}, 1 \mathrm{H}, \mathrm{CH}_{2}\right), 4.32(\mathrm{t}, J=10.0 \mathrm{~Hz}, 1 \mathrm{H}$, H-2' $), 4.20(\mathrm{~d}, J=3.0 \mathrm{~Hz}, 1 \mathrm{H}, \mathrm{H}-4), 4.08\left(\mathrm{~d}, J=2.7 \mathrm{~Hz}, 1 \mathrm{H}, \mathrm{H}-4^{\prime}\right)$, $3.92(\mathrm{t}, J=9.6 \mathrm{~Hz}, 1 \mathrm{H}, \mathrm{H}-2), 3.86-3.77\left(\mathrm{~m}, 3 \mathrm{H}, \mathrm{H}-5^{\prime}\right.$ and $\left.\mathrm{H}-6\right)$, $3.74-3.60\left(\mathrm{~m}, 3 \mathrm{H}, \mathrm{H}-5\right.$ and $\left.\mathrm{H}-6^{\prime}\right), 3.52(\mathrm{dd}, J=9.2,3.1 \mathrm{~Hz}, 1 \mathrm{H}, \mathrm{H}-3)$, $3.40\left(\mathrm{t}, J=7.1 \mathrm{~Hz}, 2 \mathrm{H} \mathrm{CH}_{2}\right), 1.61\left(\mathrm{q}, J=7.4 \mathrm{~Hz}, 2 \mathrm{H}, \mathrm{CH}_{2}\right), 1.41(\mathrm{sex}$, $\left.J=7.4 \mathrm{~Hz}, 2 \mathrm{H}, \mathrm{CH}_{2}\right), 0.97\left(\mathrm{t}, J=7.4 \mathrm{~Hz}, 3 \mathrm{H}, \mathrm{CH}_{3}\right) .{ }^{13} \mathrm{C} \mathrm{NMR}$ $\left(\mathrm{CD}_{3} \mathrm{OD}, 100 \mathrm{MHz}\right): \delta 162.7,161.0,143.6,132.0,129.1,126.7,120.4$, 113.4, 86.1, 85.2, 84.7, 81.2, 80.8, 70.8, 69.6, 69.0, 68.5, 67.5, 67.1, $62.9,62.6,39.9,32.7,21.1,14.1$. HRMS calculated for $\left[\mathrm{C}_{29} \mathrm{H}_{37} \mathrm{~F}_{2} \mathrm{~N}_{4} \mathrm{O}_{12} \mathrm{~S}\right]^{+}$703.2099, found 703.2097.

3-\{4-[(Butylamino)carbonyl]-1H-1,2,3-triazol-1-yl\}-3,3'-dideoxy-3'-[4-(3,4,5-trifluorophenyl)-1H-1,2,3-triazol-1-yl]-1, $1^{\prime}$ sulfanediyl-di- $\beta$-D-galactopyranoside 39 . To a solution of compound $23(26 \mathrm{mg}, 0.032 \mathrm{mmol})$ and $\mathrm{CuI}(0.6 \mathrm{mg}, 0.003 \mathrm{mmol})$ in DMF $(3 \mathrm{~mL})$ methyl propiolate $(0.004 \mathrm{~mL}, 0.048 \mathrm{mmol})$ was added followed by DIPEA $(0.005 \mathrm{~mL}, 0.032 \mathrm{mmol})$, and the mixture was stirred $54 \mathrm{~h}$ at $50{ }^{\circ} \mathrm{C}$. The reaction was quenched with satd aq $\mathrm{NH}_{4} \mathrm{Cl}$ followed by evaporation of the solvent, and water was added. The mixture was extracted twice with DCM, and the organic phases were washed with brine, dried, and evaporated. The obtained residue was stirred with a solution of butylamine $20 \%$ in $\mathrm{MeOH}$ for 3 days at rt. The solution was evaporated and the residue was purified with flash chromatography (DCM:MeOH 9:1) to give $39(13.2 \mathrm{mg}, 60 \%)$ as an amorphous white solid. $[\alpha]_{\mathrm{D}}{ }^{20} 11.9\left(c \quad 0.67, \mathrm{CH}_{3} \mathrm{OH}\right) .{ }^{1} \mathrm{H}$ NMR $\left(\mathrm{CD}_{3} \mathrm{OD}, 400 \mathrm{MHz}\right): \delta 8.59(\mathrm{~s}, 1 \mathrm{H}, \mathrm{Ph}), 8.55(\mathrm{~s}, 1 \mathrm{H}, \mathrm{Ph}), 7.43(\mathrm{dd}, J$ $=8.8,6.5 \mathrm{~Hz}, 2 \mathrm{H}, \mathrm{Ph}), 4.93\left(\mathrm{dd}, J=10.4,2.9 \mathrm{~Hz}, 2 \mathrm{H}, \mathrm{H}-3\right.$ and $\left.\mathrm{H}-3^{\prime}\right)$, 4.87 (obscured by water $\mathrm{H}-1$ and $\left.\mathrm{H}-1^{\prime}\right), 4.76\left(\mathrm{~m}, 2 \mathrm{H}, \mathrm{H}-2\right.$ and $\left.\mathrm{H}-2^{\prime}\right)$, $4.14\left(\mathrm{~d}, J=2.7 \mathrm{~Hz}, 1 \mathrm{H}, \mathrm{H}-4\right.$ or H-4 $\left.{ }^{\prime}\right), 4.12(\mathrm{~d}, J=2.7 \mathrm{~Hz}, 1 \mathrm{H}, \mathrm{H}-4$ or H-4'), 3.89-3.78 (m, 4H, H-6), 3.70 (m, 2H, H-5 and $\left.\mathrm{H}-5^{\prime}\right), 3.39$ (t, J $\left.=7.0 \mathrm{~Hz}, 2 \mathrm{H}, \mathrm{CH}_{2}\right), 1.60\left(\mathrm{~m}, 2 \mathrm{H}, \mathrm{CH}_{2}\right), 1.40\left(\mathrm{~m}, 2 \mathrm{H}, \mathrm{CH}_{2}\right), 0.96(\mathrm{t}, J$ $\left.=7.3 \mathrm{~Hz}, 3 \mathrm{H}, \mathrm{CH}_{3}\right) \cdot{ }^{13} \mathrm{C} \mathrm{NMR}\left(\mathrm{CD}_{3} \mathrm{OD}, 100 \mathrm{MHz}\right): \delta 162.7,145.5$, $143.6,141.7,126.8,122.8,110.8,110.7,110.6,86.7,86.6,81.4,81.3$, 69.6, 68.8, 68.4, 68.3, 62.8, 39.9, 32.7, 21.1, 14.1. HRMS calculated for $\left[\mathrm{C}_{27} \mathrm{H}_{34} \mathrm{~F}_{3} \mathrm{~N}_{7} \mathrm{O}_{9} \mathrm{SNa}\right]^{+}$712.1980, found 712.1989.

Direct Binding Fluorescence Polarization Experiments Determining Probe Properties. Human galectin- $1^{38}$ and galectin$3^{39}$ were expressed and purified as earlier described. A fixed concentration $(0.02$ or $0.004 \mu \mathrm{M})$ of fluorescein-labeled saccharide probes 25-26 in PBS were mixed with a range of galectin in dilution from 0.001 to $50 \mu \mathrm{M}$ (in PBS) in a final volume of $160 \mu \mathrm{L}$ at room temperature, in black 96-well plates (FluoroNunc). Polarization was measured using a PheraStarFS plate reader with software PHERAstar Mars version 2.10 R3 (BMG, Offenburg, Germany) and fluorescence anisotropy of fluorescein tagged probes measured with excitation at $485 \mathrm{~nm}$ and emission at $520 \mathrm{~nm} . K_{\mathrm{d}}$ and SEM values were determined in GraphPad Prism as previously described. ${ }^{31}$

Competitive Fluorescence Polarization Experiments Determining Galectin Affinities. Human galectin- $1,{ }^{38}$ galectin- $3,{ }^{39}$ and galectin-3 $\mathrm{C}^{39}$ were expressed and purified as earlier described. Fluorescence polarization experiments were performed on a PheraStarFS plate reader with software PHERAstar Mars version 2.10 R3 (BMG, Offenburg, Germany) and fluorescence anisotropy of fluorescein tagged probes measured with excitation at $485 \mathrm{~nm}$ and emission at $520 \mathrm{~nm}$. $K_{\mathrm{d}}$ values were determined in GraphPad Prism as previously described ${ }^{31,32}$ with specific conditions for each galectin as described below. Compounds were dissolved in neat DMSO at 10-50 $\mathrm{mM}$ and diluted in PBS to 3-6 different concentrations to be tested in duplicates. $K_{\mathrm{d}}$ average and SEM were calculated from 4 to 25 singlepoint measurements from at least two independent experiments showing between 10 and $90 \%$ inhibition. Galectin- 1 experiments for all compounds and galectin-3 experiments for 5-17 and 43 were performed as described. ${ }^{28}$ Galectin-3 and galectin-3C experiments for high-affinity compounds $19-21$ and 36-39 were done at $20{ }^{\circ} \mathrm{C}$ with galectin-3 or galectin-3C at $10 \mathrm{nM}$ and the fluorescent probe molecule 26 at $4 \mathrm{nM} ; 100 \mathrm{nM}$ BSA was included to prevent significant loss of galectin-3 and the probe at these low concentrations.

Competitive Isothermal Titration Calorimetry. All ITC experiments were performed on a MicroCal PEAQ-ITC (Malvern) at $301 \mathrm{~K}$ with 16 injections of $2.5 \mu \mathrm{L}$ per injection (first injection 0.4 $\mu \mathrm{L}$ ) of the ligand into the protein. Stock solutions of the ligands and the competitive ligand were prepared in DMSO to 10 and $50 \mathrm{mM}$, respectively. The ligands were diluted with buffer to concentrations between 0.1 and $0.2 \mathrm{mM}$ and a DMSO concentration of $5 \%$. All experiments were performed in a competitive manner with galectin$3 \mathrm{C}^{40}$ concentrations between 0.011 and $0.022 \mathrm{mM}$ and competitive ligand concentrations of $0.25-2 \mathrm{mM}$ in the cell. The DMSO concentrations in the cell and syringe were matched to avoid any heat of DMSO dilution. All thermograms were integrated using NITPIC, ${ }^{41,42}$ and the titrations curves were fitted using SEDPHAT ${ }^{43}$ with error estimates using the automatic confidence interval search with projection method, and all figures were made in GUSSI. ${ }^{44}$

Co-crystallization of Galectin-3C with Compounds 36 and 37. Galectin- $3 \mathrm{C}^{40}$ solutions $(12 \mu \mathrm{L}, 19.2 \mathrm{mg} / \mathrm{mL}$ in $10 \mathrm{mM}$ phosphate pH 7.5 (36) or 7.4 (37), $100 \mathrm{mM} \mathrm{NaCl}, 10 \mathrm{mM} \beta$-mercaptoethanol, and $\left.0.02 \% \mathrm{NaN}_{3}\right)$ were mixed with either compound 36 or $37(1.3 \mu \mathrm{L}$, $50 \mathrm{mM}$ in $100 \%$ DMSO) and incubated on ice for $30 \mathrm{~min}$. Crystallization drops of $2+2 \mu \mathrm{L}$ were set up over $1 \mathrm{~mL}$ of reservoir solution (30\% PEG 4000, 0.1 M Tris/HCl pH 7.5, 0.1 M MgCl $2,0.4$ $\mathrm{M} \mathrm{NaSCN}, 7.9 \mathrm{mM} \beta$-mercaptoethanol). Immediately after setup, the drops were seeded by adding $0.25 \mu \mathrm{L}$ of crystals of apo-galectin-3C that had been crushed using a Hampton Research seed bead in a stabilizing solution (reservoir solution). Co-crystals of 36 and 37 with 
galectin-3C formed within a few days. Crystals measuring $0.1 \times 0.05 \times$ $0.05 \mathrm{~mm}^{3}$ were flash-frozen in cryo solution ( $15 \%$ glycerol, $25.5 \mathrm{w} / \mathrm{v} \%$ PEG 4000, $250 \mathrm{mM}$ NaSCN, $85 \mathrm{mM}$ Tris $/ \mathrm{HCl} \mathrm{pH} \mathrm{7.5,} 85 \mathrm{mM}$ $\mathrm{MgCl}_{2}, 2.5 \mathrm{mM} 36$ or 37).

Data Collection and Structure Solution of Galectin-3C in Complex with 36 and 37. Data to $1.2 \AA$ for compound 36 were collected at $100 \mathrm{~K}$ at station I911-3 of MAX-lab, Lund, Sweden $(\lambda=$ $1.0000 \AA$ ) , equipped with a marMosaic $225 \mathrm{~mm}$ CCD detector. Then 200 images with $1^{\circ}$ rotation were collected in two passes with different exposure times. The data for compound 37 were collected at EMBL beamline P14 at DESY, Hamburg, Germany, equipped with a PILATUS $6 \mathrm{M}$ detector. Data were collected at $100 \mathrm{~K}(\lambda=1.0000$ $\AA$ ). Then 2000 images were collected of $0.1^{\circ}$ rotation with exposure time of $0.05 \mathrm{~s}$ per image. Data for both structures were integrated using XDS and scaled using XSCALE. ${ }^{45}$ The structures were refined using Refmac5 for compound 36 and phenix.refine ${ }^{46}$ for compound 37 and PDB 3ZSL (stripped of water molecules and alternate conformations) as the starting model, first by rigid-body refinement. Then $5 \%$ of the total reflections were randomly set aside for cross validation. The models were then subjected to model building and maximum likelihood refinement, gradually increasing the resolution to $1.2 / 1.15 \AA$ with anisotropic $B$-factors. After initial refinement of the protein coordinates in Refmac5/phenix.refine, ${ }^{47}$ the coordinates of 36 and 37 were fitted to the electron density using Coot. ${ }^{48}$ Further model building and manipulations were done in Coot. Restraints were generated using the Jligand program ${ }^{49}$ for 36 and using eLBOW ${ }^{50}$ from Phenix for 37 . The structures were refined until convergence and individual anisotropic atomic displacement parameters for each atom were refined. Water molecules were added to positive difference density peaks more than $4.5 \sigma$ or $5 \sigma$ above the mean and also present in the $2 m\left|F_{\mathrm{o}}\right|-D\left|F_{\mathrm{c}}\right|$ map at $1 \sigma$ level. Riding hydrogen atoms were added in the final stages of refinement. Refinement statistics are listed in Table S1, Supporting Information. Molecular images were generated using PyMOL (Schrodinger LLC). Model validation and analysis were performed using MolProbity ${ }^{51}$ and PDB_REDO. ${ }^{52}$ Coordinates have been deposited in the Protein Data Bank with accession numbers 5OAX for compound $\mathbf{3 6}$ and SODY for compound 37.

\section{ASSOCIATED CONTENT}

\section{S Supporting Information}

The Supporting Information is available free of charge on the ACS Publications website at DOI: 10.1021/acs.jmedchem.7b01626.

Synthetic procedure of compounds 4-16, 22-24, 3133, 35, and 42-43; ${ }^{1} \mathrm{H}$ and ${ }^{13} \mathrm{C}$ spectra; fluorescence polarization titration curves, competitive isothermal titration curves; crystallographic data (PDF) Molecular formula strings (CSV)

\section{Accession Codes}

The structure coordinates and corresponding structure factor file of galectin-3C in complex with compounds 36-37 have been deposited in the Protein Data Bank with accession codes 5OAX for compound 36 and 5ODY for compound 37.

\section{AUTHOR INFORMATION}

\section{Corresponding Author}

*Phone: +46 46 2228218. Fax: +46 46 2228209. E-mail: ulf. nilsson@chem.lu.se.

\section{ORCID}

Mikael Akke: 0000-0002-2395-825X

Derek T. Logan: 0000-0002-0098-8560

Ulf J. Nilsson: 0000-0001-5815-9522

\section{Notes}

The authors declare the following competing financial interest(s): UJN and HL are shareholders in Galecto Biotech $\mathrm{AB}$, a company developing galectin inhibitors.

\section{ACKNOWLEDGMENTS}

This work was supported by the Swedish Research Council (grants nos. 621-2009-5326, 621-2012-2978), the Royal Physiographic Society, Lund, the European Community's Seventh Framework Program (FP7-2007-2013) under grant agreement no. HEALTH-F2-2011-256986, project acronym PANACREAS, a project grant awarded by the Knut and Alice Wallenberg Foundation (KAW 2013.0022), and Galecto Biotech AB, Sweden. We thank Guillaume Pompidor at the I911 beamline of the MAX IV Laboratory and the P14 beamline of EMBL Hamburg, DESY, for beam time and assistance in data collection.

\section{ABBREVIATIONS USED}

CRD, carbohydrate-recognition domain; DIPEA, diisopropylethylamine; 5-FAM alkyne, 5-carboxyfluorescein propargylamide; ITC, isothermal titration calorimetry; SEM, standard error of measurement

\section{REFERENCES}

(1) Lajoie, P.; Goetz, J. G.; Dennis, J. W.; Nabi, I. R. Lattices, Rafts, and Scaffolds: Domain Regulation of Receptor Signaling at the Plasma Membrane. J. Cell Biol. 2009, 185, 381-385.

(2) Boscher, C.; Dennis, J. W.; Nabi, I. R. Glycosylation, Galectins and Cellular Signaling. Curr. Opin. Cell Biol. 2011, 23, 383-392.

(3) Liu, F. T.; Rabinovich, G. A. Galectins: Regulators of Acute and Chronic Inflammation. Ann. N. Y. Acad. Sci. 2010, 1183, 158-182.

(4) Liu, F.-T.; Rabinovich, G. A. Galectins as Modulators of Tumour Progression. Nat. Rev. Cancer 2005, 5, 29-41.

(5) Lin, C.-I.; Whang, E. E.; Donner, D. B.; Jiang, X.; Price, B. D.; Carothers, A. M.; Delaine, T.; Leffler, H.; Nilsson, U. J.; Nose, V.; Moore, F. D.; Ruan, D. T. Galectin-3 Targeted Therapy with a Small Molecule Inhibitor Activates Apoptosis and Enhances Both Chemosensitivity and Radiosensitivity in Papillary Thyroid Cancer. Mol. Cancer Res. 2009, 7, 1655-1662.

(6) MacKinnon, A. C.; Farnworth, S. L.; Hodkinson, P. S.; Henderson, N. C.; Atkinson, K. M.; Leffler, H.; Nilsson, U. J.; Haslett, C.; Forbes, S. J.; Sethi, T. Regulation of Alternative Macrophage Activation by Galectin-3. J. Immunol. 2008, 180, 26502658.

(7) Glinsky, V. V.; Kiriakova, G.; Glinskii, O. V.; Mossine, V. V.; Mawhinney, T. P.; Turk, J. R.; Glinskii, A. B.; Huxley, V. H.; Price, J. E.; Glinsky, G. V. Synthetic Galectin-3 Inhibitor Increases Metastatic Cancer Cell Sensitivity to Taxol-Induced Apoptosis In Vitro and In Vivo. Neoplasia 2009, 11, 901-909.

(8) MacKinnon, A. C.; Gibbons, M. A.; Farnworth, S. L.; Leffler, H.; Nilsson, U. J.; Delaine, T.; Simpson, A. J.; Forbes, S. J.; Hirani, N.; Gauldie, J.; Sethi, T. Regulation of Transforming Growth Factor- $\beta 1$ Driven Lung Fibrosis by Galectin-3. Am. J. Respir. Crit. Care Med. 2012, 185, 537-546.

(9) Sörme, P.; Qian, Y.; Nyholm, P. G.; Leffler, H.; Nilsson, U. J. Low Micromolar Inhibitors of Galectin-3 Based on 3'-Derivatization of NAcetyllactosamine. ChemBioChem 2002, 3, 183-189.

(10) Sörme, P.; Arnoux, P.; Kahl-Knutsson, B.; Leffler, H.; Rini, J. M.; Nilsson, U. J. Structural and Thermodynamic Studies on Cation- $\pi$ Interactions in Lectin-Ligand Complexes: High-Affinity Galectin-3 Inhibitors through Fine-Tuning of an Arginine-Arene Interaction. J. Am. Chem. Soc. 2005, 127, 1737-1743.

(11) Rauthu, S. R.; Shiao, T. C.; André, S.; Miller, M. C.; Madej, É.; Mayo, K. H.; Gabius, H. J.; Roy, R. Defining the Potential of Aglycone Modifications for Affinity/selectivity Enhancement against Medically 
Relevant Lectins: Synthesis, Activity Screening, and HSQC-Based NMR Analysis. ChemBioChem 2015, 16, 126-139.

(12) Dion, J.; Deshayes, F.; Storozhylova, N.; Advedissian, T.; Lambert, A.; Viguier, M.; Tellier, C.; Dussouy, C.; Poirier, F.; Grandjean, C. Lactosamine-Based Derivatives as Tools to Delineate the Biological Functions of Galectins: Application to Skin Tissue Repair. ChemBioChem 2017, 18, 782-789.

(13) Salameh, B. A.; Leffler, H.; Nilsson, U. J. 3-(1,2,3-Triazol-1-yl)1-Thio-Galactosides as Small, Efficient, and Hydrolytically Stable Inhibitors of Galectin-3. Bioorg. Med. Chem. Lett. 2005, 15, 33443346.

(14) Giguère, D.; Bonin, M. A.; Cloutier, P.; Patnam, R.; St-Pierre, C.; Sato, S.; Roy, R. Synthesis of Stable and Selective Inhibitors of Human Galectins-1 and -3. Bioorg. Med. Chem. 2008, 16, 7811-7823.

(15) Tejler, J.; Salameh, B.; Leffler, H.; Nilsson, U. J. Fragment-Based Development of Triazole-Substituted O-Galactosyl Aldoximes with Fragment-Induced Affinity and Selectivity for Galectin-3. Org. Biomol. Chem. 2009, 7, 3982-3990.

(16) Gigure, D.; André, S.; Bonin, M. A.; Bellefleur, M. A.; Provencal, A.; Cloutier, P.; Pucci, B.; Roy, R.; Gabius, H. J. Inhibitory Potential of Chemical Substitutions at Bioinspired Sites of $\beta$-D-Galactopyranose on Neoglycoprotein/cell Surface Binding of Two Classes of Medically Relevant Lectins. Bioorg. Med. Chem. 2011, 19, 3280-3287.

(17) Marchiori, M. F.; Pires Souto, D. E.; Oliveira Bortot, L.; Francisco Pereira, J.; Kubota, L. T.; Cummings, R. D.; Dias-Baruffi, M.; Carvalho, I.; Campo, V. L. Synthetic 1,2,3-Triazole-Linked Glycoconjugates Bind with High Affinity to Human Galectin-3. Bioorg. Med. Chem. 2015, 23, 3414-3425.

(18) André, S.; Cejas Ortega, P. J.; Perez, M. A.; Roy, R.; Gabius, H. J. Lactose-Containing Starburst Dendrimers: Influence of Dendrimer Generation and Binding-Site Orientation of Receptors (Plant/animal Lectins and Immunoglobulins) on Binding Properties. Glycobiology 1999, 9, 1253-1261.

(19) Vrasidas, I.; André, S.; Valentini, P.; Böck, C.; Lensch, M.; Kaltner, H.; Liskamp, R. M.; Gabius, H.-J.; Pieters, R. J. Rigidified Multivalent Lactose Molecules and Their Interactions with Mammalian Galectins: A Route to Selective Inhibitors. Org. Biomol. Chem. 2003, 1, 803-810.

(20) Roy, R.; Cao, Y.; Kaltner, H.; Kottari, N.; Shiao, C.; Belkhadem, K.; André, S.; Manning, J. C.; Murphy, P. V.; Gabius, H.-J. Teaming up Synthetic Chemistry and Histochemistry for Activity Screening in Galectin-Directed Inhibitor Design. Histochem. Cell Biol. 2017, 147, 285-301.

(21) Wang, H.; Huang, W.; Orwenyo, J.; Banerjee, A.; Vasta, G. R.; Wang, L. X. Design and Synthesis of Glycoprotein-Based Multivalent Glyco-Ligands for Influenza Hemagglutinin and Human Galectin-3. Bioorg. Med. Chem. 2013, 21, 2037-2044.

(22) Abbassi, L.; Chabre, Y. M.; Kottari, N.; Arnold, A. A.; André, S.; Josserand, J.; Gabius, H.-J.; Roy, R. Multifaceted Glycodendrimers with Programmable Bioactivity through Convergent, Divergent, and Accelerated Approaches Using Polyfunctional Cyclotriphosphazenes. Polym. Chem. 2015, 6, 7666-7683.

(23) Cumpstey, I.; Sundin, A.; Leffler, H.; Nilsson, U. J. C2Symmetrical Thiodigalactoside Bis-Benzamido Derivatives as HighAffinity Inhibitors of Galectin-3: Efficient Lectin Inhibition through Double Arginine-Arene Interactions. Angew. Chem., Int. Ed. 2005, 44, 5110-5112.

(24) Cumpstey, I.; Salomonsson, E.; Sundin, A.; Leffler, H.; Nilsson, U. J. Double Affinity Amplification of Galectin-Ligand Interactions through Arginine-Arene Interactions: Synthetic, Thermodynamic, and Computational Studies with Aromatic Diamido Thiodigalactosides. Chem. - Eur. J. 2008, 14, 4233-4245.

(25) Rajput, V. K.; MacKinnon, A.; Mandal, S.; Collins, P.; Blanchard, H.; Leffler, H.; Sethi, T.; Schambye, H.; Mukhopadhyay, B.; Nilsson, U. J. A Selective Galactose-Coumarin-Derived Galectin-3 Inhibitor Demonstrates Involvement of Galectin-3-Glycan Interactions in a Pulmonary Fibrosis Model. J. Med. Chem. 2016, 59, 8141-8147.

(26) Nilsson, U.; Leffler, H.; Mukhopadhyay, B.; Rajput, V. Novel Galactoside Inhibitors of Galectins. WO2013110704 A1, Aug 1, 2013.
(27) Salameh, B. A.; Cumpstey, I.; Sundin, A.; Leffler, H.; Nilsson, U. J. 1H-1,2,3-Triazol-1-yl Thiodigalactoside Derivatives as High Affinity Galectin-3 Inhibitors. Bioorg. Med. Chem. 2010, 18, 5367-5378.

(28) Delaine, T.; Collins, P.; Mackinnon, A.; Sharma, G.; Stegmayr, J.; Rajput, V. K.; Mandal, S.; Cumpstey, I.; Larumbe, A.; Salameh, B. A.; Kahl-Knutsson, B.; van Hattum, H.; van Scherpenzeel, M.; Pieters, R. J.; Sethi, T.; Schambye, H.; Oredsson, S.; Leffler, H.; Blanchard, H.; Nilsson, U. J. Galectin-3-Binding Glycomimetics That Strongly Reduce Bleomycin-Induced Lung Fibrosis and Modulate Intracellular Glycan Recognition. ChemBioChem 2016, 17, 1759-1770.

(29) Zürcher, M.; Diederich, F. Structure-Based Drug Design: Exploring the Proper Filling of Apolar Pockets at Enzyme Active Sites. J. Org. Chem. 2008, 73, 4345-4361.

(30) Peterson, K.; Weymouth-Wilson, A.; Nilsson, U. J. Aryl Sulfonates in Inversions at Secondary Carbohydrate Hydroxyl Groups: A New and Improved Route Toward 3-Azido-3-Deoxy- $\beta$-DGalactopyranosides. J. Carbohydr. Chem. 2015, 34, 490-499.

(31) Sörme, P.; Kahl-Knutsson, B.; Huflejt, M.; Nilsson, U. J.; Leffler, $\mathrm{H}$. Fluorescence Polarization as an Analytical Tool to Evaluate Galectin-Ligand Interactions. Anal. Biochem. 2004, 334, 36-47.

(32) Cumpstey, I.; Carlsson, S.; Leffler, H.; Nilsson, U. J. Synthesis of a Phenyl Thio- $\beta$-D-Galactopyranoside Library from 1,5-Difluoro-2,4Dinitrobenzene: Discovery of Efficient and Selective Monosaccharide Inhibitors of Galectin-7. Org. Biomol. Chem. 2005, 3, 1922-1932.

(33) van Scherpenzeel, M.; Moret, E. E.; Ballell, L.; Liskamp, R. M. J.; Nilsson, U. J.; Leffler, H.; Pieters, R. J. Synthesis and Evaluation of New Thiodigalactoside-Based Chemical Probes to Label Galectin-3. ChemBioChem 2009, 10, 1724-1733.

(34) Lowary, T. L.; Hindsgaul, O. Recognition of Synthetic OMethyl, Epimeric, and Amino Analogues of the Acceptor $\alpha$-L-Fuc p-(1 $\rightarrow$ 2)- $\beta$-D-Gal p-OR Glycosyltransferases. Carbohydr. Res. 1994, 251, $33-67$.

(35) Zhang, L.; Wei, G.; Du, Y. Synthesis of Neu5Ac-GalFunctionalized Gold Glyconanoparticles. Carbohydr. Res. 2009, 344, 2083-2087.

(36) Rajput, V. K.; Leffler, H.; Nilsson, U. J.; Mukhopadhyay, B. Synthesis and Evaluation of Iminocoumaryl and Coumaryl Derivatized Glycosides as Galectin Antagonists. Bioorg. Med. Chem. Lett. 2014, 24, 3516-3520.

(37) Mandal, S.; Nilsson, U. J. Tri-Isopropylsilyl Thioglycosides as Masked Glycosyl Thiol Nucleophiles for the Synthesis of S-Linked Glycosides and Glyco-Conjugates. Org. Biomol. Chem. 2014, 12, $4816-4819$.

(38) Salomonsson, E.; Larumbe, A.; Tejler, J.; Tullberg, E.; Rydberg, H.; Sundin, A.; Khabut, A.; Frejd, T.; Lobsanov, Y. D.; Rini, J. M.; Nilsson, U. J.; Leffler, H. Monovalent Interactions of Galectin-1. Biochemistry 2010, 49, 9518-9532.

(39) Massa, S. M.; Cooper, D. N. W.; Leffler, H.; Barondes, S. H. L29, an Endogenous Lectin, Binds to Glycoconjugate Ligands with Positive Cooperativity. Biochemistry 1993, 32, 260-267.

(40) Diehl, C.; Engström, O.; Delaine, T.; Håkansson, M.; Genheden, S.; Modig, K.; Leffler, H.; Ryde, U.; Nilsson, U. J.; Akke, M. Protein Flexibility and Conformational Entropy in Ligand Design Targeting the Carbohydrate Recognistion Domain of Galectin-3. J. Am. Chem. Soc. 2010, 132, 14577-14589.

(41) Keller, S.; Vargas, C.; Zhao, H.; Piszczek, G.; Brautigam, C. A.; Schuck, P. High-Precision Isothermal Titration Calorimetry with Automated Peak-Shape Analysis. Anal. Chem. 2012, 84, 5066-5073.

(42) Scheuermann, T. H.; Brautigam, C. A. High-Precision, Automated Integration of Multiple Isothermal Titration Calorimetric Thermograms: New Features of NITPIC. Methods 2015, 76, 87-98.

(43) Zhao, H.; Piszczek, G.; Schuck, P. SEDPHAT - A Platform for Global ITC Analysis and Global Multi-Method Analysis of Molecular Interactions. Methods 2015, 76, 137-148.

(44) Brautigam, C. A. Calculations and Publication-Quality Illustrations for Analytical Ultracentrifugation Data. Methods Enzymol. 2015, 562, 109-133.

(45) Kabsch, W. Xds. Acta Crystallogr., Sect. D: Biol. Crystallogr. 2010, $66,125-132$. 
(46) Afonine, P. V.; Grosse-Kunstleve, R. W.; Echols, N.; Headd, J. J.; Moriarty, N. W.; Mustyakimov, M.; Terwilliger, T. C.; Urzhumtsev, A.; Zwart, P. H.; Adams, P. D. Towards Automated Crystallographic Structure Refinement with Phenix.refine. Acta Crystallogr., Sect. D: Biol. Crystallogr. 2012, 68, 352-367.

(47) Murshudov, G. N.; Skubák, P.; Lebedev, A. A.; Pannu, N. S.; Steiner, R. A.; Nicholls, R. A.; Winn, M. D.; Long, F.; Vagin, A. A. REFMAC5 for the Refinement of Macromolecular Crystal Structures. Acta Crystallogr., Sect. D: Biol. Crystallogr. 2011, 67, 355-367.

(48) Emsley, P.; Lohkamp, B.; Scott, W. G.; Cowtan, K. Features and Development of Coot. Acta Crystallogr., Sect. D: Biol. Crystallogr. 2010, 66, 486-501.

(49) Lebedev, A. A.; Young, P.; Isupov, M. N.; Moroz, O. V.; Vagin, A. A.; Murshudov, G. N. JLigand: A Graphical Tool for the CCP4 Template-Restraint Library. Acta Crystallogr., Sect. D: Biol. Crystallogr. 2012, 68, 431-440.

(50) Moriarty, N. W.; Grosse-Kunstleve, R. W.; Adams, P. D. Electronic Ligand Builder and Optimization Workbench (eLBOW): A Tool for Ligand Coordinate and Restraint Generation. Acta Crystallogr., Sect. D: Biol. Crystallogr. 2009, 65, 1074-1080.

(51) Chen, V. B.; Arendall, W. B.; Headd, J. J.; Keedy, D. A.; Immormino, R. M.; Kapral, G. J.; Murray, L. W.; Richardson, J. S.; Richardson, D. C. MolProbity: All-Atom Structure Validation for Macromolecular Crystallography. Acta Crystallogr., Sect. D: Biol. Crystallogr. 2010, 66, 12-21.

(52) Joosten, R. P.; Long, F.; Murshudov, G. N.; Perrakis, A. The PDB_REDO Server for Macromolecular Structure Model Optimization. IUCrJ 2014, 1, 213-220. 